NBER WORKING PAPER SERIES

\title{
ACCIDENTS WILL HAPPEN? UNINTENTIONAL INJURY, MATERNAL EMPLOYMENT, AND CHILD CARE POLICY
}

\author{
Janet Currie \\ V. Joseph Hotz \\ Working Paper 8090 \\ http://www.nber.org/papers/w8090 \\ NATIONAL BUREAU OF ECONOMIC RESEARCH \\ 1050 Massachusetts Avenue \\ Cambridge, MA 02138 \\ January 2001
}

Anna Aizer, Jwahong Min, and Mehdi Farsi provided excellent research assistance. Tor Eriksson, Jan Van Ours, and seminar participants at the Milan SOLE 2000 meetings and the University of Texas at Austin provided helpful comments. The authors thank NIH and NSF for financial support. The views expressed herein are those of the authors and not necessarily those of the National Bureau of Economic Research.

(C) 2001 by Janet Currie and V. Joseph Hotz. All rights reserved. Short sections of text, not to exceed two paragraphs, may be quoted without explicit permission provided that full credit, including $\odot$ notice, is given to the source. 
Accidents Will Happen? Unintentional Injury, Maternal Employment, and Child Care Policy

Janet Currie and V. Joseph Hotz

NBER Working Paper No. 8090

January 2001

JEL No. I18

\begin{abstract}
In western countries, accidents are the leading cause of death and injury among children, far surpassing diseases as a health threat. We examine the effect of maternal employment and child care policy on rates of accidental injury using both micro data from the National Longitudinal Survey of Youth (NLSY) and Vital Statistics records. We find that the effects of maternal employment on unintentional injuries to children vary by demographic group, with the effects being positive for blacks and negative for whites in models that control for child-specific fixed effects.

Estimates from both individual-level NLSY and Vital Statistics data suggest that the effects of maternal employment may be mediated by child care regulations. Most notably, requiring training beyond high school for caregivers reduces the incidence of both fatal and non-fatal accidents. Other types of regulation have mixed effects on unintentional injuries, suggesting that child care regulations create winners and losers. In particular, while some children may benefit from safer environments, others that appear to be squeezed out of the more expensive regulated sector and are placed at higher risks of injury.
\end{abstract}

Janet Currie

Department of Economics

UCLA

Los Angeles, CA 90095-1477

and NBER

currie@simba.sscnet.ucla.edu

\section{Joseph Hotz}

Department of Economics

UCLA

Los Angeles, CA 90095-1477

and NBER

hotz@ucla.edu 


\section{Introduction}

Most western countries have witnessed a dramatic increase in the labor force participation of mothers with young children in recent years. In the United States, the participation of women with children less than 6 years of age rose from $46.8 \%$ to $62.3 \%$ between 1980 and 1996 (U.S. Committee on Ways and Means, 1998). These changes imply that many young children are being cared for by someone other than their mother for large portions of the day.

Despite the magnitude of these changes, we know little about their consequences for the well-being of children. Existing work has focused largely on effects of maternal employment on children's test scores (c.f. Desai et al., 1989; Parcel and Menaghan, 1994; Blau and Grossberg, 1992; Niedell, 2000; and Ruhm, 2000), with often inconclusive results. Controlling for unobserved factors that may be correlated with both maternal employment and child outcomes is a difficult problem in this literature, given that cognitive outcomes are likely to be affected by many factors in addition to maternal supervision at a point in time.

This paper focuses on accidental injuries as one important measure of child well-being. Injuries are the leading cause of death and morbidity among American children older than one year (Bonnie et al., 1999). What effect maternal labor force participation has on the incidence of unintended injuries among children is unclear. On the one hand, working mothers generate higher family income that enables them to purchase higher quality child care that may minimize the risk of injury for their children. On the other hand, working mothers may have less time (and energy) to provide adequate supervision of their children and/or may substitute poor quality nonmaternal supervision when they are working. Either may lead to higher injury rates. Thus, the relationship between injury rates and maternal employment is likely to be mediated by the quality of the care of young children and the regulations that influence it. 
We examine the relationship between accidental injuries, maternal employment, and child care policy using data from several sources. Individual-level information about accidents requiring medical attention comes from the Child-Mother files of the National Longitudinal Survey of Youth (NLSY). Time-series data about accidental deaths across states is constructed using the Vital Statistics Detail Mortality (VSDM) and Vital Statistics Detail Natality (VSDN) data from 1979 to 1996. Information about state child care regulations was collected by Hotz and Kilburn (1997, 2000). We also make use of data from the March Current Population Surveys (CPS) to construct measures of the demographic characteristics of states.

We find that the effects of maternal employment on unintentional injuries to children vary by demographic group, with the effects being positive for blacks and negative for whites in models that control for child-specific fixed effects. We also present evidence that indicates that the effects of maternal employment on rates of injuries to children are mediated by the quality of child care as measured by the stringency of state regulations of this care. In particular, we find strong and consistent evidence in both of the data sets that requiring caregivers to have education beyond high school reduces the incidence of both fatal and non-fatal accidents. For example, the estimates imply that education requirements reduce accidental deaths among 1 to 5 year olds by $16 \%$ overall. Conversely, requiring more than one inspection per year has statistically significant but mixed effects on childhood injury rates. Such inspections increase the incidence of non-fatal injuries requiring medical attention among children of less educated mothers, but reduce the incidence of fatal injuries among blacks. At the same time, we find that requiring insurance lowers the incidence of fatal injuries among whites, but has no effect among blacks.

We perform an auxiliary analysis of the relationship between child care regulations and the modes of child care that parents choose. We find evidence consistent with the view that more 
stringent regulations increase injury rates by squeezing some children out of the more expensive regulated sector and into unregulated care. An important exception to this evidence is the effect of imposing minimum educational requirements for child care providers. Such requirements do not appear to reduce the use of regulated care. Overall, these findings suggest that some forms of child care regulation create winners and losers, depending on whether or not these "crowdout" effects outweigh the beneficial direct effects of regulation on the safety of child care environments.

The rest of the paper is laid out as follows. Section 1 provides some background information about variation in rates of accidental injuries, and child care regulation. Section 2 lays out a conceptual model. Section 3 describes our data sources. Section 4 provides an overview of our empirical model. Results appear in Section 5 and Section 6 concludes.

\section{Background}

\section{a) Systematic Variations in Injury Rates}

Accidents (or unintentional injuries as public health experts prefer to call these events) are the leading cause of death among children over 1 year old. Table 1 shows the six leading causes of death for children of ages 1 to 3, and 4 to 5. These figures are calculated using the 1996 Detailed Mortality data for the U.S. It is striking how much more important unintentional injuries are than any form of infectious disease for young children.

These mortality statistics for children shed light only on the tip of the iceberg of underlying injuries. For each death that results from childhood injury, it is estimated that there are more than 1,000 emergency room visits and an unknown number of injuries that receive no medical treatment (Children's Safety Network, 1991). It is estimated that between 1987 and 1995, 6,600 American children died annually from preventable injuries, 246,000 children per 
year were hospitalized, and injuries resulted in almost 9 million emergency room visits and 12 million physician visits each year (National Safe Kids Campaign, 1998).

It often been argued in the past that the accidents experienced by children are simply the normal consequence of growing up. For example, a 1999 Institute of Medicine Report on injury prevention remarks, "For centuries, human injuries have been regarded either as random and unavoidable occurrences ('accidents' or 'acts of God') or as untoward consequences of human malevolence or carelessness. From this perspective, the main strategies for prevention are prayer and human improvement" (Bonnie et al., 1999). But epidemiological evidence clearly indicates systematic differences across socioeconomic groups in the risks of childhood injuries. For example, injury rates vary dramatically by race within the United States, with black children being 1.7 times more likely than white children to die from unintentional injuries (National SAFE KIDS Campaign, 1998).

Additional evidence that many U.S. accidents are actually preventable comes from declining rates of deaths due to unintentional injuries within the U.S. Between 1987 and 1995, the number of deaths due to unintentional injuries among children younger than 14 fell from 15.6 per 100,000 to 11.5 per 100,000 , a decline of 26 percent. Deaths to motor vehicle occupants, drownings, and deaths due to pedestrian and bicycle accidents and fires all declined.

Also, the majority of U.S. childhood accidents occur between May and August, and most unintentional injury related deaths among older children happen in the evening hours when children are most likely to be out of school and unsupervised. In addition, some types of injuries are most common among the children of single parents and young mothers, which again suggests that lack of proper supervision plays a role (National SAFE KIDS Campaign, 1998).

Finally, we note that childhood death rates from causes such as burns, drownings, and 
falls are systematically lower in Europe than they are in the United States, even though rates of death from congenital anomalies and malignancies are comparable in most developed industrial countries (Williams and Miller, 1992). At the same time, the higher rates of childhood injuries in the U.S. relative to other countries may have little to do with differences in the way children are cared for. For example, given that the U.S. is a large country while the Netherlands is a small one, it may always be the case that there are higher numbers of automobile fatalities among both adults and children in the United States simply because Americans drive longer distances. Similarly, backyard swimming pools may be more common in the United States than in some other countries, leading to more drownings.

In summary, the available evidence suggests that unintentional injuries are a very important cause of death and injury for young children and that they are not "Acts of God" but avoidable. Thus, improved supervision of children is likely to be an important way to prevent such injuries. We now turn to the evidence on the relationship between the risk of injury to children and one form of childhood supervision, namely non-parental child care.

\section{b) Child Care and Injury Risk}

The available evidence about child care and injury risk suggests two things. First, licensed, regulated, day care centers are actually a very safe place for children relative to other settings. Sacks et al. (1989) estimate that the risk of an injury requiring medical attention is 14.3 per 100 children annually in day care, compared to 35 per 100 children in the community at large. Similarly, other researchers (c.f. Briss et al.) have found relatively low rates of injuries in such child care settings.

However, a second finding is that even regulated child care centers are often not without significant risks of injury. While most states do not keep detailed information about deaths to 
children that occur in child care facilities, those that do suggest that $12 \%$ of the 2,260 accidental deaths to children between the ages of 1 and 4 years old in 1995 occurred in child care settings. This figure rises to $20 \%$ if we exclude deaths to children who were automobile passengers from the denominator (U.S. News, 1997). Furthermore, a recent report from the U.S. Consumer Product Safety Commission found that many licensed child care centers had safety hazards including unsafe equipment, a failure to use safety gates, window blind cords within children's reach, and allowing children to wear clothing with drawstrings (U.S. CPSC, 1999). These findings suggest that there may be scope for reducing injury rates by improving regulation of licensed child care providers.

\section{Conceptual Model}

In this section, we outline a simple model of parental choice over time allocation and production of "child quality." Фarents are assumed to maximize a utility function:

$$
U=f(X, L, Q: c, e),
$$

by choosing goods $(X)$, leisure $(L)$, and child quality $(Q)$, taking child and family characteristics $(c)$, and random shocks (e), as given. They maximize this function subject to the following budget constraint:

$$
p X+w L=Y+(T-L) w,
$$

where $w$ is the wage, $p$ is a vector of prices, $Y$ is non-labor income, and $T$ is the total endowment of time. Households also face a production function that describes the way that goods and nonworking time (leisure) can be combined to produce child quality:

$$
Q=g(X, L: c, v),
$$

\footnotetext{
${ }^{1}$ See Ribar (1992) and Blau and Hagy (1997) for similar models of parental labor supply and child care choice.
} 
where $v$ is a random shock.

In this simple framework, increases in work activity reduce the amount of $L$ available for investment in child quality, but increase the amount of $X$ that could be invested. Child care is one of the $X$ variables that can be purchased. It is useful to think of there being two types of child care, $X_{r}$ which is regulated and $X_{u}$ which is unregulated. These two forms of child care have prices $p_{r}$ and $p_{u}$, respectively. To the extent that higher quality, and safer, child care is costly to produce, binding child care regulations that regulate quality and safety are likely to increase $p_{r}$ relative to $p_{u}$. In a world of full information about child care settings and the risk of injuries to children, more stringent regulations will "crowd" some parents - namely those with a lower willingness to pay for higher quality care_- "out" of regulated care due to this higher price.

However, in the real world, parents may be uncertain about the quality of care their children will receive from a particular child care provider. For example, parents may not know exactly what type of care the provider provides or how safe a particular setting is. The imposition of minimum quality and safety standards on day care centers can solve the information problem faced by parents, at least to the extent that these standards are enforced. Some forms of regulation may actually change the production function for child quality, making it easier to avoid unintentional injury with a given level of parental effort. For example, a highly trained caregiver may be more likely than a less skilled person to educate parents about dangerous products and practices (such as drawstrings on children's clothing). A skilled caregiver is also more likely to teach children about safety practices proactively rather than punishing them after-the-fact for violating rules. As a result, such regulations may increase both the actual quality of care in the regulated sector and the amount that parents are willing to pay.

The potential for the imposition of minimum quality standards, via regulation, to solve 
the informational problems consumers face with respect to certain types of goods and services has been noted in the economics literature on product quality and liability. For example, Klein and Leffler (1981) argue that the maintenance of licensure systems that impose minimum quality standards on service providers may have beneficial welfare effects in markets for goods and services in which product quality is difficult to monitor. Imposing standards in such markets can "assure" consumers of the quality of the goods and services they receive to the extent that a provider's investment in meeting such standards either generates a higher stream of earnings or results in higher costs (fines) to the provider if these minimum standards are violated 2

In summary, regulating the child care market by imposing minimum standards on some segment of that market can be a two-edged sword. While children in child care settings subject to binding regulation may receive higher quality care, regulation is also likely to drive some children out of the regulated sector. Thus, the overall effect on child safety is ambiguous and a positive effect of regulation on accident rates may reflect this "crowdout" effect. We investigate this possibility further below.

\section{Data}

This study merges state-level data about child care regulations with individual-level data from the NLSY and its Child-Mother files as well as Vital Statistics data. These two sources of individual-level data are complementary. On the one hand, the NLSY has information about all medically attended injuries, rather than just the small fraction of injuries resulting in death. To our knowledge, this data has not previously been exploited. Moreover, the NLSY has a great deal

\footnotetext{
${ }^{2}$ Also see Leland (1979) and Shapiro (1986) for more on the role of licensing and imposing minimum quality standards in markets for goods and services with hard-to-monitor quality attributes. See Lowenstein and Tinnin (1992) and Hotz and Kilburn $(1997,2000)$ for more on the application of such arguments to the market for child care services.
} 
of demographic information about mothers and children, as well as repeated observations on the same child. On the other hand, the Child-Mother information from the NLSY is reported by the mother, and is likely to be subject to reporting biases, as discussed below.

The VSDM is a census of all deaths in the U.S., so selective reporting is not an issue. It contains information about types of accidents and causes of death. our findings on the effects of child care regulations on accident death rates among children, we conduct separate analyses on child deaths due to cancer and to car passengers. With respect to the former, one should not expect to find any systematic relationship between child care regulations and the incidence of cancer deaths. Furthermore, the most plausible way that such regulations might affect accidental deaths to automobile passengers would be through some form of crowdout, e.g., the stringency of regulations affecting the commuting patterns and distances to and from day care facilities. We present results below that examine the effects of regulations (and other variables) on the death rates due to these two causes.

Finally, the large sample sizes in the Vital Statistics data offer some distinct advantages. For example, in the NLSY data we sometimes find significant effects for whites and not for blacks. It is not clear whether these differing estimates reflect the smaller sample size for blacks, or true differences in behavior. In the VSDM, sample sizes are large for both blacks and whites, making it easier to detect true differences.

The child care data and the two sources of individual-level data sets are described in further detail in section b) below. We now turn to a description of our data on child care regulation.

\footnotetext{
${ }^{3}$ The NLSYCM actually also has information about the type of accident. However, of the 1563 accidents in our data set, only 50 involved car passengers. By way of comparison, 745 accidents involved falls, and thus could have occurred either at home or in child care settings. In contrast to the Vital Statistics data, it was not possible to identify
} 


\section{a) Data about Child Care Regulations}

The child care regulations we focus on include ratios of children to caregivers; whether there is more than one mandatory inspection per year; whether it is mandatory to have insurance; and whether head caregivers are required to have training beyond a high school diploma. These forms of regulation tend to be applied to different types of child care settings. For example, direct inspections are generally used for licensed family homes while insurance is usually required only for day care centers. It is possible that large institutions find it easier to obtain insurance in the private market than small family home operations. Minimum education requirements also apply mainly to day care centers. We have coded these last three categories of regulation as ' 1 ' if the regulation applies to either family homes or to daycare centers. Regulation of child-to-caregiver ratios is prevalent for both day care centers and family homes. Hence we include measures for both types of child care setting.

Table 2 shows the number of states that require head caregivers in either setting to have more than a high school degree, that require insurance, or that have more than one required inspection per year. Mean maximum ratios of children to caregivers for two age groups are also shown. Table 2 shows that on average, there was little change in these ratios over time, something that is also true within states. Potentially more significant changes in state child care regulations occurred between 1986 and 1987, when 6 states added requirements that head caregivers have some training beyond a high school degree. Six more states added this

\footnotetext{
any large class of accidents in the NLSCM that did or did not occur in child care.

${ }^{4}$ For further information on the collection of these state child care regulation data, see Hotz and Kilburn (2000).

${ }^{5}$ We also examined group sizes, which are often regulated. However, there is generally little difference between the maximum group size and the maximum ratio. Moreover ratios are a somewhat less ambiguous concept than the group size. For example, in California in 1996 a licensed family home with two caregivers was allowed to have 12 children, including 4 infants and 8 older children. Here the ratio of children to caregivers is clearly 6 . However, the group size for infants is 4 and for toddlers is 8 , even though all 12 children may be together for most of the day.
} 
requirement between 1990 and 1991. Often such training would consist of a specified number of courses in child development from a local community college. Finally, Table 2 indicates that there has been a slow decline in the use of direct inspections and an increase in the number of states that require at least some types of child care providers to carry insurance.

\section{b) Individual-Level Data}

The National Longitudinal Survey of Youth began in 1978 with approximately 6,000 young men and 6,000 young women. These individuals have been followed up every year since. In 1986, the NLSY began following the children of the young women, at two-year intervals. The Child-Mother data in the NLSY offers a unique and previously untapped source of information about medically attended, non-fatal injuries among children. Questions about accidents were asked beginning with the 1988 survey. Mothers are asked: 1) whether the child had an accident in the past 12 months that required medical attention; and 2) whether the child ever had an accident (not necessarily in the past 12 months) requiring hospitalization. If the mother answered yes to either of these questions, she was asked the specific month and year of the three most recent accidents.

Because of the way that these questions were asked, we have accident information for different time windows for different children. For example, if the mother did not report any accidents in 1987, then we know nothing about 1986. But if she reported an accident in January 1987, and a previous accident in May 1986, then we have a history of accidents from May 1986 to December 1987. In total, we have accident data for 3,394 mothers with 6,206 children aged 1 to 5 . We excluded infants under one year because unlike older children, they are much more

\footnotetext{
${ }^{6}$ If there was an accident requiring medical attention reported in the same month and year as an accident requiring hospitalization, then we assumed that these were one and the same accident. While it would be interesting to look at
} 
likely to die from essentially medical causes such as congenital anomalies. The data spans the period 1983 to 1996 . The children were surveyed at least once and up to four times in our sample. Organizing our data into quarters (because of the seasonal patterns in accident rates noted above, and so that we can more precisely measure the mother's work status) yields a maximum of 24 quarters of data for each child, and a minimum of 1 quarter. The average child had approximately 8 quarters of accident data.

Information about the mother's employment was obtained from the NLSY Work History file. The work history file has information about every mother's labor force status and usual hours of work for every week beginning with the first week of 1978. Mothers who reported working for at least one week during the quarter were coded as having worked during that quarter. We have a total of 44,369 quarters of child life data.

The NLSY Child-Mother data also includes questions about child care in the 1986 and 1988 surveys which applied to the last month prior to the date of interview. In 1992, 1994 and 1996 questions were asked about child care in the first three years of each child's life. Because of this design, we have data about child care arrangements for only a subset of our sample covering 10,480 quarters of child life. We will use this subset of the sample to examine the effect of regulation on the choice of child care mode.

We obtained data on maternal and child characteristics from the main NLSY and its Child-Mother files. These variables included: the child's age, race, and gender; whether or not a spouse was present; whether there were older or younger siblings in the household; whether the maternal grandmother and grandfather worked when the mother was aged 14; whether the maternal grandfather was present when the mother was 14; the mother's score on the Armed 
Forces Qualifications Test (a test of job skills); and the mother's education.

Some of these variables are likely to have a direct effect on accident rates. For example, the presence of an older sibling may mean that a child is more likely to be exposed to ageinappropriate toys. Other variables such as those describing the maternal grandparents and AFQT have been shown in previous work using the NLSY to be important predictors of maternal employment and socioeconomic status and may also be related to accident propensities.

The first part of Table 3 shows means of all our variables for the entire sample in the NLSY Child-Mother files, as well as by race and maternal education categories. The overall accident rate is around 3\%, with a rate of $2.4 \%$ for blacks and $3.6 \%$ for whites. The pattern by education is u-shaped, with the accident rate first increasing in education and then decreasing. These patterns are consistent with evidence from other sources that suggests that there are socioeconomic biases in the reporting of medically-attended injuries. In particular, more expensive day care centers and those with high proportions of white children are more likely to report such injuries, even though we would expect these centers to have lower actual injury rates.

Maternal employment rates are high for all groups except high school dropouts, and increase with education. The other variables in Table 3 show largely the patterns that one would expect. For example, black children and children of high school dropouts appear to be disadvantaged in terms of maternal education and presence of a father-figure.

The second panel of Table 3 shows rates of unintentional injuries, maternal employment, and child and family characteristics by type of child care, for those mothers and children for whom we have child care information. Note, that this sample is much younger on average than the "accident" sample. Child care regulations generally distinguish between child care centers and licensed family homes. The NLSY data do not allow us to make this distinction very 
precisely. Hence we split the data into three groups: nurseries, day care centers, family group homes, and preschools; other types of child care; and no non-maternal child care. The first two categories correspond roughly to regulated and unregulated child care settings.

There are two striking things about this part of the table. First, almost half of the mothers who report "no care" are employed. This raises the question of whether even very young children are being left unattended while their mothers work. Some mothers, for example, might arrange to work shifts while their children were sleeping. Second, accident rates are much higher for children in child care than for other children. Since this finding is in sharp contrast to the literature discussed above, it suggests that perhaps the same injury is more likely to result in a doctor visit when a child is in some form of child care than when the child is looked after by his or her mother. Thus, regulation that pushed children out of child care and into maternal care could cause a spurious reduction in the number of accidents requiring medical attention.

Reporting issues of this sort make it important to verify any findings from the NLSY with the Vital Statistics data, and to look directly at the crowdout issue as we do below.

\section{b) Vital Statistics Data}

The National Mortality Detail Files contain information about every death in the United States. The file has information about race, the state of birth, state of residence, age at death, and cause of death. We use data from the 1979 to 1996 detail files. We focus on deaths due to unintentional injuries among children 1 to 5 years old.

In order to calculate a denominator to use in the computation of death rates, we use data from the National Natality Detail Files (a census of all births in the U.S.) in combination with the Mortality Detail Files to calculate the number of children who were born in a particular state and 
year and who were still living as of each particular age. We calculate rates separately for 51 states, 14 years (from 1983 to 1996), and 2 age groups. Disaggregating further by race and gender yields 5,712 possible cells.

These cells are matched to additional demographic data obtained from the Current Population Survey's March files (CPS). The Current Population Survey samples approximately 100,000 persons per year. We use these data to calculate the fraction of children in each state, year, and age group that is in poverty, urban, black or hispanic, as well as the median family income of these children, fraction of children whose mother's have a high school education, and the fraction of children in one parent families. All of these indicators might be expected to influence accident rates independent of maternal employment status. Finally, we use the CPS to calculate the fraction of mothers in each state, year, age, and race category (black, nonblack) who were employed.

Of the 5,712 cells in the Vital Statistics data, 452 cells for black children have no corresponding observations on maternal employment from the CPS. Hence, these cells are lost. We lose an additional 54 cells because of missing data about the maximum ratio of children to caregivers in family homes, and 290 cells because of missing data about the maximum ratio in day care centers. These cells are generally from the first years of our data. $\mathrm{B}$ We exclude one

\footnotetext{
${ }^{7}$ Note that this procedure requires us to use the state of birth of the decedent rather than the state of death. Since state of birth and state of death are the same for most of the children in our sample, we feel that this is acceptable. The alternative would be to use state of death, and to try to find some other source of information about the number of children of each age in each state and year. Sample sizes in data sources like the CPS and the SIPP are too small to give accurate answers for small states, and the Census is not updated frequently enough. Another problem is that numbers of children can be computed only for U.S. born children, so that immigrants are excluded from our analyses of death rates using Vital Statistics data.

${ }^{8}$ We have re-estimated the Vital Statistics models discussed below excluding the ratio in day care centers and using the 290 cells that are missing this information. The inferences are very similar to those reported in this paper, with one exception: Requiring insurance has a positive and significant effect on accidental death rates among blacks in this sample. We have also re-estimated the models including the ratio in day care centers and excluding the ratio in family homes. The coefficients on each type of ratio are remarkably similar to those reported below, whether or not
} 
(small) cell with a reported accident rate of 34.4 per 1,000 . Thus, we use 4,915 cells in the analyses we present below.

Table 4 provides an overview of these Vital Statistics data. The first column shows the weighted mean computed over all cells, while the minimum and maximum counts across cells are shown in columns 2 and 3. Table 4 indicates that there is a great deal of variation in both outcomes and state characteristics across cells. Among children, deaths due to unintentional injury are (mercifully) rare events. The overall rate is 0.165 per 1,000 . Nineteen percent of these deaths represent children killed while riding as car passengers, making it one of the largest single categories of deaths due to unintentional injury. Children killed by cars as pedestrians are included in the "other accident" category, since these accidents could have occurred while children were in child care. The incidence of cancer deaths is slightly higher than the incidence of child deaths to car passengers at 0.039 per 1,000 .

Although it is not shown in the table, it is remarkable how much variation in accident rates there is by race. The mean accident rate is 0.220 per 1,000 for blacks, with a maximum rate for a "black" cell of 6.36. Among whites, the maximum death rate is only 2.77. Most of this variation stems from differences in the incidence of other accidents rather than deaths to car passengers.

The variation across cells in our CPS variables is also striking, with for example, poverty rates varying between $5 \%$ and $28 \%$. However, small cell sizes in the CPS lead us to have cells in which, for example, all observations are either urban or not urban.

The figures shown at the bottom of Table 4 indicate that the smallest cell in the Vital Statistics data has 18 observations. Given the possibility of rates being driven by outliers in small the other is included in the regression model. 
cells, we repeated the analyses described below aggregating the Vital Statistics data up to the state, year and age group level (i.e. suppressing the differences in accident rates by race and gender). The estimates of the effects of regulation obtained this way were very similar to those reported below.

\section{Empirical Specification}

The conceptual model discussed above highlights the fact that work status and child quality are both endogenously chosen. Thus, while it is possible to solve equations (1), (2) and (3) and derive an expression for child quality as a function of work status, $p, w, Y$ and $c$, a failure to properly control for all of the determinants of child quality and work status is likely to yield a biased estimate of the effect of work status on child quality.

\section{a) Estimation Using Individual-Level Data}

We begin our analysis of the NLSY data by estimating Ordinary Least Squares (OLS) models of the form:

$$
\mathrm{ACCIDENT}_{i t}=\alpha_{0}+\alpha_{1} \mathrm{WORKSTAT}_{i t}+\alpha_{2}^{\prime} \mathrm{C}_{i t}+\alpha_{3}^{\prime} \mathrm{SEASON}_{t}+\alpha_{4 t} \mathrm{YEAR}_{t}+\varepsilon_{i t},
$$

where accident is a dummy variable equal to 1 if child $i$ had an accident requiring medical attention in quarter $t$; WORKSTAT is a dummy equal to 1 if the mother was working, $\mathrm{C}$ is the vector of child and family characteristics described above, SEASON is a vector of dummy variables for fall, summer, and spring, YEAR is a vector of year dummies, and $\varepsilon_{i t}$ is an idiosyncratic shock. The model does not explicitly control for income. Hence, $\alpha_{1}$ measures the full effect of working, rather than the effect of working with income constant.

The OLS coefficient $\alpha_{1}$ may be biased up or down in this model. In particular, suppose that some mothers are more productive both in the labor force and in the production of child 
quality. If these high productivity mothers are more likely to work than others, then a failure to fully control for differences in productivity will lead to a spurious negative correlation between maternal employment and child accident rates. Child-specific factors may also be an important source of bias. Suppose, for example, that a child is particularly at risk of accidents, and that, for this reason, the mother does not work. Then once again, there will be a spurious negative association between accidents and maternal employment.

In order to control for these biases, we also estimate models that include child fixed effects:

$$
\operatorname{ACCIDENT}_{i t}=\beta_{i}+\beta_{1} \text { WORKSTAT }_{i t}+\beta_{2}^{\prime} \tilde{\mathrm{C}}_{i t}+\beta_{3}^{\prime} \mathrm{SEASON}_{t}+\beta_{4 t} \mathrm{YEAR}_{t}+v_{i t}
$$

where $\beta_{i}$ is the child fixed effect, and $\tilde{\mathrm{C}}$ is a more limited set of time-varying observable variables. It is important to note that these fixed effects models control for any permanent component of income, as well as for other time-invariant, child-specific factors. Thus, they address the question of whether, holding permanent income fixed, maternal employment is related to a higher or lower probability of a childhood accident requiring medical attention.

Equations (4) and (5) are estimated for the entire sample, and for subsamples defined by race or education. As discussed above, one rationale for doing this is that the reporting of injuries requiring medical attention in survey data may vary systematically by race and/or education. Including child fixed effects should control for this reporting bias, at least to the extent that mothers report injuries consistently over time.

It is also possible that maternal employment has differing effects by group. The model suggests that reducing the amount of maternal time invested in the child is likely to have negative

\footnotetext{
${ }^{9} \mathrm{We}$ also estimated models that controlled for mother rather than child fixed effects. The estimates were quite similar to the child fixed effects models reported below.
} 
consequences, everything else being equal. However, everything else is not equal. The quality of non-maternal care that children receive may be better or worse than the care that would have been provided by the mother, and the relative quality of care may vary systematically by socioeconomic status. Suppose for example, that a high school dropout mother works. She may be more likely than other working mothers to leave her child with someone who is more skilled in producing child quality than she is herself. For instance, she might leave the child with her own mother or in a quality subsidized child care center such as Head Start. In this case, maternal employment would be associated not only with more income, but also with higher quality time inputs, and thus might have a positive impact on child quality. One might also see such effects by race. For example, we know that poor black children have much higher rates of participation in Head Start than poor white children (Currie and Thomas, 1995).

On the other hand, a more educated mother might end up leaving her child with a less skilled person when she goes to work. In this case, maternal employment could have a harmful effect on child quality if the negative effects of lower quality time inputs are not fully offset by increases in income. To the extent that the fixed effects capture increases in income associated with maternal employment, the coefficient on maternal employment will capture the positive or negative effects of substituting non-maternal for maternal time.

In order to begin to get at the mediating effect of child care quality, we also estimate versions of model (5) that include measures of child care regulations and interactions between maternal employment and child care regulations. These models take the form:

$$
\begin{aligned}
\operatorname{ACCIDENT}_{i t}= & \gamma_{i}+\gamma_{1} \mathrm{WORKSTAT}_{i t}+\gamma_{2}^{\prime} \mathrm{CCREG}_{i t}+\gamma_{3}^{\prime} \mathrm{CCREG}_{i t} \cdot \text { WORKSTAT }_{i t} \\
& +\gamma_{4}^{\prime} \tilde{\mathrm{C}}_{i t}+\gamma_{5}^{\prime} \mathrm{SEASON}_{t}+\gamma_{6 t} \mathrm{YEAR}_{t}+\eta_{i t},
\end{aligned}
$$

where CCREG is a vector of child care regulations. Because the regulations vary only at the 
state-year level, we correct the standard errors to allow for correlations within state-year cells. The question addressed in these models is whether child care regulation mitigates any negative effects (or exacerbates any positive effects) of maternal employment.

\section{b) Estimation Using Combined Vital Statistics and CPS Data}

We use the combined Vital Statistics and CPS data to estimate models of the following form:

$$
\mathrm{ACCMORT}_{g s t}=\delta_{i}+\delta_{1}^{\prime} \mathrm{DEMO}_{g s t}+\delta_{2} \mathrm{WORKMOM}_{g s t}+\delta_{3}^{\prime} \mathrm{CPS}_{s t}+\delta_{4 s} \mathrm{STATE}_{s}+\delta_{5 t} \mathrm{YEAR}_{t}+\xi_{i t}
$$

where $g$ indexes the demographic group, $s$ indexes the state, $t$ indexes the year, ACCMORT is the mortality rate in the cell, DEMO is a vector of indicators describing the demographic group, WORKMOM is the number of mothers working in the group, state, and year, CPS is a vector of other characteristics of states and years constructed using the CPS as described above, STATE is a vector of state dummies, YEAR is a vector of year dummies, and $\xi$ is an error term. All models are estimated by weighted least squares, where the weights are given by the cell sizes.

In addition to (7), we estimate a model that includes the vector of child care regulation variables described in Table 2, and we also estimate these models separately by race. Although we include state and year effects in these models, it is possible that the estimated effects of the policy variables are biased by the omission of other things that are varying within states over time. The inclusion of the constructed CPS variables mitigates this problem to some extent by allowing us to control, for example, for state-specific trends in maternal education and poverty.

As noted above, we estimate models with child cancer death rates as the dependent variable to assess the plausibility of our estimated child care regulation effects and the adequacy of our various attempts to control for endogeneity bias. Cancer deaths may be affected by general socioeconomic conditions, but are unlikely to respond to child care regulation. Thus, if we found 
effects of child care regulation in models of cancer deaths, we would have to conclude that the child care regulations were proxying for some other, unobserved determinant of mortality.

Finally, in an attempt to get at the mechanisms underlying the effects of child care regulation, we distinguish between the effects of regulation on deaths to car passengers, and effects on all other types of accidental deaths. Accidents to car passengers are unlikely to have taken place while the child is in child care. Thus, effects of child care regulation on these deaths cannot reflect the direct effects of regulation on child care settings.

Regulation could still affect the probability of these deaths indirectly however, either by changing driving patterns or through "spillovers" of knowledge about safe practices from caregivers to parents. For example, if caregivers expect children to arrive in car seats, parents may be more likely to use them. Thus, while we expect regulation to have larger effects on other accidents than on fatalities among children riding in cars, we cannot rule out the possibility that there will be some effect on these deaths.

\section{Results}

\section{a) Results Using NLSY Data}

The first two parts of Table 5 present estimates of the coefficients on maternal employment from equations (4) and (5). Estimates are presented for the full sample, as well as six subsamples defined for various racial and maternal education categories. The coefficients on the other variables included in the model are suppressed from Table 5 in order to conserve space, but models corresponding to the first section of Table 5 are shown in Appendix Table 1.

The coefficients are generally consistent with what one would expect on the basis of the literature described above. For example, the presence of a younger sibling is associated with a lower probability of accidents, while the presence of older siblings increases accident rates. 
Males have higher accident rates, while blacks and Hispanics report lower rates. Accident rates rise with age until age 4 and then fall again for 5 year olds, and are higher in the summer and fall than in the other quarters of the year. One anomalous finding is that maternal education has little effect on reported injury rates, and the probability of reporting an injury requiring medical attention increases slightly with AFQT scores. We believe that these findings reflect differential reporting by more/less educated (high/low AFQT) women.

The OLS estimates in Table 5 suggest that maternal employment has no effect on accident rates except among blacks. However, among blacks, the effect is quite large relative to the mean probabilities in Table 3. Maternal employment decreases the probability of an accident requiring medical attention by two thirds of a percentage point, which is a decrease of $30 \%$ below the baseline probability for blacks shown in Table 3 . Note that the types of reporting biases discussed above (e.g. child care providers being more likely than parents to seek medical attention for a given injury) cannot explain this finding.

Controlling for child fixed effects changes these results a good deal. The negative effect for blacks becomes even stronger, but the estimated effect for whites is now positive and statistically significant at the $90 \%$ level of confidence. The results for whites suggest that, conditional on permanent income and other fixed maternal and child characteristics, increases in maternal employment increase accident probabilities among white children. The fixed effects estimates also suggest that OLS estimates are likely to be biased downwards due to the type of selection bias discussed above, namely, that mothers who are most likely to be employed are also less likely to have children who are prone to have accidents.

Table 5 suggests that maternal employment has no effect on accident rates overall. However, this result masks large differences between groups. There is a strong negative effect of 
maternal employment on accident probabilities for black children, as well as a positive effect for white children that is significant at the $90 \%$ level of confidence.

We do not find significant effects when we divide the sample by maternal education, suggesting that the differential racial effects cannot be explained by differences in maternal education levels. Other possible explanations for the negative effect of maternal employment on accident probabilities among black children include more hazardous home environments (possibly due to residential segregation) and/or greater utilization of high quality day care centers, at least by some children. Unfortunately, it is difficult to test these hypotheses directly using our data.

We can, however, examine the effects of child care regulation. The last panel of Table 5 explores these effects by estimating models in the form of equation (6). The model specification is similar to the child fixed effects models shown in Panel 2 of Table 5, except that the models include both the indicators for child care regulation and interactions of these variables with whether or not the mother was working.

It is difficult to interpret the main effects of child care regulation in these models which include child fixed effects. There is generally little variation in regulation over the time that we observe a particular child. Moreover, these main effects may pick up omitted characteristics of states. However, the fact that mothers may or may not be employed at a point in time creates a great deal of additional variation that can be exploited. The coefficients on the interaction terms can be interpreted as telling us what would happen if a child's mother went to work in a high regulation state rather than a low regulation state.

\footnotetext{
${ }^{10}$ We also estimated models in which each type of regulation and its interaction were included separately. The results were very similar to those reported here.
} 
As discussed above, child care regulations may have either positive or negative effects on accident rates. Effective regulation is expected to reduce accident rates in child care centers that are subject to regulation. However, regulation may also squeeze people out of the regulated sector, which could increase accident rates. Spillovers from child care regulation to home care are also possible.

The third panel of Table 5 shows that the main effects of regulation are not generally statistically significant. An exception is that having more than one mandatory inspection annually is associated with lower rates of accidents requiring medical attention. Turning to the interactions, the most striking result is that minimum education requirements for caregivers have strong negative effects on overall accident rates. In the subgroups, this effect is significant for white children, but not for blacks. However, we do find some evidence of a beneficial effect of minimum education requirements for blacks when we examine the Vital Statistics data below. This suggests that the contrast between results for blacks and whites here may be an artifact of the smaller sample size for blacks.

When we conduct our analysis separately by maternal education categories, we find that the beneficial effects of minimum education requirements are concentrated among children whose mothers do not have a high school degree and among children with college educated mothers. It is interesting to note that the differences between maternal care and substitute care may be largest for these two groups, creating the largest scope for regulation of child care to mediate the effects of maternal employment.

The only other significant effect of regulation in Table 5 is that requiring more than one annual inspection per year increases unintentional injuries among children of high school dropouts. This pattern could arise if, for example, less educated mothers were most likely to be 
pushed out of regulated care by inspections, a hypothesis that is investigated further below.

\section{b) Results Using Vital Statistics Data}

Estimates from models estimated using the aggregate Vital Statistics data are shown in Table 6. The table shows the determinants of death rates from all accidents, accidents to automobile passengers, all other accidents, and cancer. As discussed above, we include cancer deaths as controls as one would not expect them to be affected by child care regulation. We also differentiate between deaths to children riding in cars, and all other accidental deaths.

The first panel shows estimates of the effect of maternal employment from models that control only for child age, sex and race. It is remarkable that these simple controls explain so much of the variation in accident rates (and especially "other accidents") across cells. These correlations suggest that state/year/age/race/sex groups with higher maternal employment rates also have higher accidental death rates. Changing the share of working mothers from zero to 1 is associated with an increase in the rate of accidental deaths of 0.05 , which can be compared to the mean of 0.165 accidental deaths per 1,000 in Table 4 . However, the second and third columns suggest that most of this effect can be attributed to an increase in deaths to children riding in cars, rather than to other accidents. Finally, the fourth column indicates that maternal employment is associated with an increase in cancer deaths, which suggests that we should take these estimates with a large grain of salt.

The second panel of Table 6 shows that including the CPS controls listed in Table 4, state effects, and year effects, as well as controls for child age, sex, and race greatly reduces the estimated effects of maternal employment, although it continues to have a significant positive effect on deaths to children in cars. This finding illustrates the fact that the share of mothers who work is highly correlated with other characteristics of the cell. The inclusion of these controls 
also greatly increases the explanatory power of the regressions.

The third panel of Table 6 shows estimates from models that include our measures of child care regulations in addition to all of the other variables described above. In contrast to the NLSY estimates discussed above, the main effects of regulation here are identified using the full time span available, and we are able to include state fixed effects to control for underlying differences between states. Hence, we expect the main effects to be interpretable as measures of the effects of regulation! $\frac{12}{2}$ he estimates in this panel indicate that requiring caregivers to have training beyond high school has large and significantly negative effect on accident rates.

Moreover, this type of regulation has a much greater effect on "other" accidents than on deaths to car passengers, and has no effect on cancer death rates.

In conjunction with the means shown in Table 4, the point estimate suggests that such a requirement could lower the incidence of "other" accidental deaths by $18 \%$. If, as suggested above, as many as $20 \%$ of "other" accidental deaths to children in this age range occur in child care, then our estimate suggests that better training of caregivers could eliminate many of these deaths. We observe similar patterns for requiring insurance, and for requiring more than one annual inspection of child care facilities. That is, both measures have small negative effects on deaths to car passengers and larger negative effects on deaths due to other accidents.

In contrast, allowing higher ratios of children to caregivers in family homes is associated with slight increases in the rates of other accidents, while increasing ratios in day care centers

\footnotetext{
${ }^{11}$ Glied (1999) also finds inconsistent and generally insignificant effects of maternal employment. She uses counts of deaths due to unintentional injury from the Vital Statistics data combined with controls similar to our CPS variables.

${ }^{12}$ Moreover, unlike the NLSCM data, we cannot identify whether any particular mother worked in the Vital Statistics data, and we know that the share of mothers who work is highly correlated with other characteristics of cells. Hence, the strategy of identifying effects of regulation by interacting maternal employment with regulation is not appropriate in these data.
} 
decrease them. Again, there is no effect on accidents to car passengers, and no effect on cancer death rates suggesting that it is plausible that the estimate represents a real effect of regulation. Relative to the Table 4 means, the point estimate suggests that each additional child represents an increase/decrease in the probability of accidental death of $3.7 \%$.

The fact that these ratios have effects of different signs (which persists if each measure is entered separately) suggests that the indirect effects of changing ratios in day care centers may outweigh the direct effects on accident rates within the day care. Suppose for example, that allowing higher ratios in day care centers draws children from less safe forms of child care into day care. Then accident rates may fall even if the day care centers themselves become slightly less safe. On the other hand, increasing the ratio in family homes increases accident rates, as one would expect if this represents the direct effect of regulation.

It is interesting to examine the effects of the control variables as well. Table 6 shows that black children and male children have about the same chance of being killed while riding in a car as other children, but that they have much higher rates of other accidents. Consistent with the literature, we find that living in a one-parent family greatly increases the probability of other fatal accidents. Poverty significantly reduces the probability of an accidental death, but this effect appears to be driven by a reduction in automobile deaths, which presumably reflects lower use of cars among the poor.

Finally, it is interesting that states with high shares of Hispanics have lower death rates from all the causes examined in Table 6, and especially from other accidents. This observation is consistent with the "epidemiological paradox" that Hispanic children tend to have better health outcomes than other children even though they are poorer on average (Hernandez and Charney, 1998). 
Table 7 shows separate estimates for blacks and whites. The estimated effects of minimum education requirements are consistent with those shown in Table 6 in that these requirements significantly reduce both types of accidents but have much stronger effects for "other" accidents than for deaths to car passengers. However, it is remarkable that the estimated effect for blacks is twice as great as the effect for whites.

An interesting set of results in Table 7 concern the differential racial effects of insurance and inspections. Table 7 suggests that mandatory insurance reduces the incidence of other accidents among whites, but not among blacks, while increasing the number of inspections has a negative effect among blacks but not among whites. Similarly, allowing higher ratios in day care centers has a larger negative effect on blacks than whites, while the effect of increasing ratios in family homes is negative, but not significant among blacks.

Recall that inspections apply mainly to family homes, while mandatory insurance applies mainly to day care centers. Thus, it is possible that these patterns are explained by differential usage of day care centers and family homes by race. As discussed above, blacks are more likely to use Head Start. But they may be less likely to use commercial child care centers (c.f. Fuller, 1992), and commercial child care facilities may be more likely to be affected by regulation than non-profit centers that are already of high quality.

\section{c) An Analysis of Choice of Child Care Mode}

We argue above that the seemingly perverse effects of some types of child care regulation on some groups (such as positive effects of more frequent inspections on accident rates among children of high school dropouts, and positive effects of lower day care ratios) may reflect a crowding out effect. By increasing the cost of regulated child care, regulation may increase the probability that a child is in an unregulated environment. Moreover, if crowdout is a significant 
problem, then our methods should provide lower bounds on the positive direct effects of child care regulation on the safety of regulated care because they reflect the combined impact of both improved safety in the child care setting and crowdout. These issues are investigated in Table 8.

The regression models underlying Table 8 are similar to equation (6) except that maternal employment and interactions between child care regulations and maternal employment are omitted. The reason for this omission is that many women in the base "no child care" group are not using child care because they are not employed (that is, the choice of child care mode and the choice of employment status are simultaneously determined). Also, these models do not control for child fixed effects since we have few observations per child in this smaller data set, although they do control for within-child correlations in the error terms.

The results in Table 8 suggest that some regulations have significant effects on mode choice. In particular, requiring insurance significantly reduces the probability that day care centers are chosen. The effect is larger for blacks than for whites, and it is larger for high school dropouts than for the college educated. Mandatory insurance is also estimated to have a negative effect on the use of other child care by blacks, which may reflect difficulties in sorting out the regulated and unregulated sectors in the NLSY data. Alternatively, regulations that crowd people out of the regulated sector may also crowd people out of the unregulated sector if the supply of spaces in the unregulated sector is not perfectly elastic.

Requiring more frequent inspections also has a negative effect on the use of child care among blacks, but does not have any statistically significant effect overall, or in other subgroups. It is perhaps noteworthy, however, that the point estimates for children of high school dropouts is very large and negative, though imprecisely estimated.

Allowing higher ratios of children to caregivers in daycares has the expected positive 
effect on the use of regulated care overall, among whites, and among those with a high school education. Allowing higher ratios in family homes is estimated to have a negative effect on the use of regulated care among high school dropouts, which may reflect strong tastes for smaller ratios among a group that historically has weaker attachment to the labor force in any case.

Finally, we find that minimum education requirements are not associated with any statistically significant crowdout effects. This result is important because it suggests that the estimated effects of minimum education requirements on accident rates are not contaminated by crowdout. Thus, minimum education requirements appear to reduce the rates of both fatal and non-fatal accidents, without pushing children out of the regulated sector.

\section{Conclusions}

We examine the effects of maternal employment on one very important but neglected indicator of child well-being, accident rates. Using individual-level data from the NLSY ChildMother files, we examine the probability that a child had an accident requiring medical attention. We find that the effect of maternal employment varies by demographic group, with blacks seeing negative effects on accident rates, and whites seeing positive effects in models that control for child fixed effects. Although this data is subject to reporting biases, we argue that these biases are unlikely to explain this differential racial effect.

Our proposed explanation for this pattern of results is that the effects of maternal employment are mediated by the quality of the alternative child care arrangements that are available. Children whose mothers have access to child care that is of better quality than maternal care see positive effects of maternal employment, while those who are in care that is of worse quality than maternal care are more likely to suffer injury when their mothers are employed. In practice, the NLSY data suggest that the interactions between maternal employment and child 
care regulation are complex. The effects vary both with the type of regulation and with the demographic group.

However, we find strong and consistent evidence that requiring care givers to have education beyond high school reduces accident rates. When we examine non-fatal accidents using the NLSY data, we find that requiring caregivers to have at least a high school education is associated with reductions in the incidence of unintentional injuries requiring medical attention among whites, among children whose mothers have less than a high school degree, and among the children of college educated mothers.

When we examine the incidence of fatal accidents using the Vital Statistics data, we see that higher education requirements for caregivers are associated with reductions in accident rates among both whites and blacks, and in fact we see larger reductions for blacks than for whites.

In an examination of the choice of child care modes, we find no evidence that higher education requirements lead to children being crowded out of the regulated sector. Thus, higher education requirements appear to be a good public policy. They reduce both fatal and non-fatal accident rates without reducing children's access to regulated care.

We find only small effects of the regulation of child-to-caregiver ratios on accident rates, although such regulation does have effects on the choice of child care mode. This finding is reminiscent of a common result in the class size and school quality literature. Lazear (1999) argues that if student/teacher ratios are currently set close to optimum levels, then one would not expect small deviations from the optimum to have a big impact on outcomes. This observation offers one potential explanation of the paradox that the most regulated aspect of child care 
quality has only small impacts on child outcomes.

On the other hand, requiring more than one inspection per year has statistically significant but mixed effects. We find that it increases the incidence of non-fatal injuries requiring medical attention among children of less educated mothers, but that it reduces the incidence of fatal injuries among blacks. Our analysis of the choice of child care modes indicates that more frequent inspections also reduce the probability that black children receive any sort of nonmaternal care. Thus, the positive direct effects of inspections on children in regulated care may be offset by crowdout. In this case, our estimates of the effects of inspection underestimate the positive direct effects of inspection on the safety of children in child care.

We also find that requiring insurance lowers the incidence of fatal injuries among whites, but not among blacks. Our analysis of choice of child care mode suggests that this type of regulation is associated with a lower probability of using day care centers, and that this effect is greater for blacks than for whites. Thus, once again, our analysis suggests that this type of regulation creates winners and losers, depending on whether or not the large crowdout effects outweigh the beneficial direct effects of regulation.

\footnotetext{
${ }^{13}$ Another analogy with the school quality literature is that that literature typically examines small changes in child/teacher ratios, and in our data, the changes in ratios over time are also small.
} 


\section{References}

Blau, David and Alison Hagy. "The Demand for Quality in Child Care”, Journal of Political Economy, 106 \#1, February 104-146.

Blau, Francine and Adam Grossberg. "Maternal Labor Supply and Children's Cognitive Development”, Review of Economics and Statistics, 74(3), August, 1992.

Bonnie, Richard J., Carolyn E. Fulco, and Catharyn T. Liverman (eds.), Reducing the Burden of Injury, (National Academy Press: Washington D.C.) 1999, page 20.

Briss, Peter A., Jeffrey Sacks, David G. Addiss, Marcie-jo Kresnow and Joann O’Neil. “A Nationwide Study of the Risk of Injury Associated with Day Care Center Attendance", Pediatrics, 93 \#3, March 1994, 364-368.

Children's Safety Network, A Data Book on Child and Adolescent Injury, (Washington, D.C.: National Center for Education in Maternal and Child Health, 1991).

Currie, Janet and Duncan Thomas, "Does Head Start Make a Difference?" The American Economic Review, June 1995.

Desai, Sonalde, Lindsay Chase-Lansdale and Robert Michael. "Mother or Market? Effects of Maternal Employment on the Intellectual Ability of 4-Year Old Children”, Demography, $26,1989$.

Fuller, Bruce. Can Government Raise Child Care Quality: The Influence of Family Demand, Poverty, and Policy (Cambridge MA: Harvard Graduate School of Education) 1992.

Glied, Sherry. "The Value of Reductions in Child Injury Mortality in the U.S.”, NBER Working Paper \#7204, July 1999.

Hernandez, Donald and Evan Charney (eds.) From Generation to Generation: the Health and Well-Being of Children in Immigrant Families (National Academy Press: Washington D.C.) 1998.

Hotz, V. Joseph and Rebecca Kilburn. "Regulating Child Care: The Effects of State Regulations on Child Care Demand and its Cost", xerox, UCLA, October 1997.

Hotz, V. Joseph and Rebecca Kilburn. "The Effects of State Regulations on Child Care Prices and Choices", xerox, UCLA, March 2000.

Klein, Benjamin and Keith Leffler. "The Role of Market Forces in Assuring Contractual Performance," Journal of Political Economy, 89, pp. 615-41, 1981.

Lazear, Edward. “Educational Production”, NBER Working Paper \#7349, September, 1999. 
Leland, Hayne. "Quacks, Lemons, and Licensing: A Theory of Minimum Quality Standards. Journal of Political Economy. 87:1328-46, 1981.

Lowenberg, A., and T. Tinnin. "Professional versus Consumer Interests in Regulation: the Case of the U.S. Child Care Industry.” Applied Economics 24, pp. 571-580, 1992.

National SAFE KIDS Campaign, Fact Sheet (Washington D.C., Dec. 1998).

Neidell, Matthew. "Early Time Investments in Children's Human Capital Development: Effects of Time in the First Year on Cognitive and Non-Cognitive Outcomes", Department of Economics, UCLA, xerox, October 2000.

Parcel Toby and Elizabeth Menaghan. Parent's Jobs and Children's Lives (New York: Aldine de Gruyter) 1994.

Ribar, David. "Child Care and the Labor Supply of Married Women: Reduced Form Evidence." Journal of Human Resources, Winter 1992.

Ruhm, Christopher. "Parental Employment and Child Cognitive Development" (NBER: Cambridge MA) Working Paper \# 7666, April 2000.

Sacks, Jeffrey J, J. David Smith, Karen Kaplan, Deborah Lambert, Richard Sattin, Keith Sikes. "The Epidemiology of Injuries in Atlanta Day-Care Centers", Journal of the American Medical Association, 262 \#12, Sept 22/29, 1989, 1641-1645.

Shapiro, Carl. "Investment, Moral Hazard, and Occupational Licensing." Review of Economic Studies. LIII:843-862, 1986.

U.S. Committee on Ways and Means, Green Book (U.S. Government Printing Office, Washington D.C.) 1998.

U.S. Consumer Product Safety Commission. "Safety Hazards in Child Care Settings" (CPSC: Washington D.C.) April 1999.

U.S. National Center for Health Statistics, National Mortality Detail File (NCHS: Washington D.C.), multiple years.

U.S. National Center for Health Statistics, National Natality Detail File (NCHS: Washington D.C.), multiple years.

U.S. News. "Day Care Dangers," www.usnews.com, August 4, 1997.

Williams, Bret C., and C. Arden Miller, "Preventive Health Care for Young Children," Pediatrics, 89 \#5 (May 1992 supplement) 982-998. 
Table 1: Six Leading Causes of Child Death in the U.S., 1996, By Age

\begin{tabular}{|c|c|c|c|c|}
\hline \multirow[b]{2}{*}{ Ranking } & \multicolumn{2}{|l|}{ 1-3 Year Olds: } & \multicolumn{2}{|l|}{4 and 5 Year Olds: } \\
\hline & Cause & $\begin{array}{l}\text { No. of } \\
\text { Deaths }\end{array}$ & Cause & $\begin{array}{l}\text { No. of } \\
\text { Deaths }\end{array}$ \\
\hline 1 & Unintentional Injuries & 1,798 & Unintentional Injuries & 1,162 \\
\hline 2 & $\begin{array}{l}\text { Congenital or Perinatal } \\
\text { Problem }\end{array}$ & 636 & Cancer & 384 \\
\hline 3 & Homicide or Assault & 362 & $\begin{array}{l}\text { Congenital or Perinatal } \\
\text { Problem }\end{array}$ & 194 \\
\hline 4 & Cancer & 362 & $\begin{array}{l}\text { Disorders of Nervous and } \\
\text { Sense Organs }\end{array}$ & 182 \\
\hline 5 & $\begin{array}{l}\text { Disorders of Nervous and } \\
\text { Sense Organs }\end{array}$ & 349 & $\begin{array}{l}\text { Infetious and Parasitic } \\
\text { Diseases }\end{array}$ & 158 \\
\hline 6 & $\begin{array}{l}\text { Infetious and Parasitic } \\
\text { Diseases }\end{array}$ & 327 & Homicide or Assault & 149 \\
\hline
\end{tabular}

Notes: The number of deaths to U.S. born children appears in parentheses. We estimate that in 1996 there were 11,751,692 U.S. born children between 1 and 3, and 8,092,613 between the ages of 4 and 5 . 
Table 2: Variation in Child Care Regulations

\begin{tabular}{|c|c|c|c|c|c|c|c|}
\hline \multirow[b]{2}{*}{ Year } & \multicolumn{7}{|c|}{ Number of States with: } \\
\hline & $\begin{array}{l}\text { Minimum } \\
\text { Education } \\
\text { Standards }\end{array}$ & $\begin{array}{c}\text { More than } \\
\text { One } \\
\text { Inspections } \\
\text { Required per } \\
\text { Year }\end{array}$ & $\begin{array}{c}\text { Insurance } \\
\text { Required }\end{array}$ & $\begin{array}{c}\text { Child-Staff } \\
\text { Ratio, } \\
\text { Day Care, } \\
\text { Child 1-3 }\end{array}$ & $\begin{array}{c}\text { Child-Staff } \\
\text { Ratio, } \\
\text { Day Care, } \\
\text { Child 4-5 }\end{array}$ & $\begin{array}{c}\text { Child-Staff } \\
\text { Ratio, } \\
\text { Family } \\
\text { Homes, } \\
\text { Child 1-3 } \\
\end{array}$ & $\begin{array}{c}\text { Child-Stafj } \\
\text { Ratio, } \\
\text { Family } \\
\text { Homes, } \\
\text { Child 4-5 }\end{array}$ \\
\hline 1983 & 16 & 13 & 18 & 8.6 & 14.7 & 5.6 & 6.4 \\
\hline 1984 & 17 & 13 & 19 & 8.5 & 14.5 & 5.6 & 6.4 \\
\hline 1985 & 18 & 14 & 19 & 8.4 & 14.6 & 5.6 & 6.4 \\
\hline 1986 & 19 & 16 & 20 & 8.3 & 14.5 & 5.6 & 6.4 \\
\hline 1987 & 25 & 14 & 21 & 8.2 & 14.1 & 5.6 & 6.5 \\
\hline 1988 & 25 & 13 & 21 & 8.3 & 14.4 & 5.5 & 6.5 \\
\hline 1989 & 25 & 13 & 22 & 8.3 & 14.4 & 5.6 & 6.6 \\
\hline 1990 & 26 & 13 & 22 & 8.3 & 14.4 & 5.6 & 6.6 \\
\hline 1991 & 32 & 12 & 23 & 8.2 & 14.4 & 5.6 & 6.6 \\
\hline 1992 & 32 & 11 & 23 & 8.2 & 14.3 & 5.7 & 6.7 \\
\hline 1993 & 34 & 11 & 23 & 8.2 & 14.4 & 5.7 & 6.9 \\
\hline 1994 & 34 & 11 & 23 & 8.2 & 14.4 & 5.7 & 6.9 \\
\hline 1995 & 34 & 9 & 23 & 8.2 & 14.3 & 5.7 & 6.9 \\
\hline 1996 & 34 & 9 & 22 & 8.2 & 14.3 & 5.7 & 6.9 \\
\hline
\end{tabular}

Notes: Minimum education required indicates that head caregivers in either family homes or day care centers must have more than a high school degree. The "insurance required" and "number of inspections $>1$ " variables are coded one if either family homes or day care centers are subject to these regulations. 
Table 3: Sample Means for NLSY Data

Panel A: By Race and Education

\begin{tabular}{|l|ccccccc|}
\hline \hline \multicolumn{1}{|c|}{ Variables } & All & Black & White & $<\boldsymbol{H S}$ & HS & $\begin{array}{c}\text { Some } \\
\text { College }\end{array}$ & College \\
\hline Accident Rate & .033 & .024 & .036 & .027 & .032 & .033 & .033 \\
Maternal Employment & .603 & .603 & .603 & .340 & .592 & .685 & .718 \\
Child Age & 3.77 & 3.86 & 3.74 & 3.93 & 3.83 & 3.79 & 3.50 \\
Child Male & .512 & .488 & .519 & .526 & .506 & .517 & .505 \\
Hispanic & .172 & & .236 & .369 & .166 & .168 & .089 \\
Black & .273 & 1.000 & .000 & .351 & .284 & .319 & .183 \\
Mother's Age & 3.3 & 29.9 & 3.5 & 29.4 & 3.1 & 3.6 & 32.1 \\
Mother Single & .304 & .586 & .198 & .516 & .345 & .262 & .111 \\
Spouse Present & .679 & .402 & .785 & .455 & .645 & .724 & .872 \\
Spouse Info. Missing & .107 & .098 & .111 & .085 & .099 & .111 & .169 \\
Younger Sib. & .296 & .291 & .299 & .337 & .277 & .293 & .311 \\
Older Sib. & .615 & .683 & .590 & .756 & .643 & .602 & .482 \\
Maternal Grandma work & .526 & .569 & .509 & .440 & .517 & .577 & .534 \\
Maternal Grandpa work & .921 & .895 & .927 & .877 & .921 & .919 & .967 \\
Maternal Grandma Ed. & 10.6 & 10.6 & 10.6 & 8.0 & 10.1 & 11.1 & 12.7 \\
Mother's Education & 12.9 & 12.7 & 13.0 & 9.3 & 12.0 & 13.8 & 16.6 \\
AFQT score & 37.3 & 20.5 & 43.6 & 10.3 & 29.7 & 43.1 & 67.8 \\
No. of Obs. & 44,369 & 12,137 & 32,232 & 5,218 & 18,964 & 11,213 & 6,986 \\
No. of Moms & 3,394 & 886 & 2,508 & 354 & 1,370 & 779 & 500 \\
No. of Children & 6,206 & 1,671 & 4,535 & 731 & 2,558 & 1,446 & 914 \\
\hline
\end{tabular}

Panel B: By Child Care Mode (Selected Variables)

\begin{tabular}{|l|ccc|}
\hline \hline \multicolumn{1}{|c|}{ Variables } & No Child Care & $\begin{array}{c}\text { Day Care, Group } \\
\text { Homes, Pre-Schools }\end{array}$ & Other Non-Maternal \\
\hline Accident Rate & .035 & .050 & .046 \\
Maternal Employment & .471 & .881 & .923 \\
Child Age & 2.52 & 2.30 & 2.13 \\
Hispanic & .171 & .113 & .182 \\
Black & .257 & .377 & .259 \\
Mother's Age & 29.7 & 29.7 & 29.8 \\
Mother Single & .287 & .294 & .237 \\
Younger Sib. & .185 & .083 & .103 \\
Older Sib. & .659 & .490 & .589 \\
Mother's Education & 12.9 & 13.7 & 13.4 \\
AFQT score & 37.3 & 42.3 & 42.8 \\
No. of Obs. & 5,533 & 1,332 & 3,615 \\
No. of Moms & 1,659 & 464 & 1,154 \\
No. of Children & 2,326 & 537 & 1,392 \\
\hline
\end{tabular}

Notes: Means for spouse present and maternal grandfather's work status when mother aged 14 are taken over all non-missing observations. 
Table 4: Descriptive Statistics for Vital Statistics Data

\begin{tabular}{|c|c|c|c|}
\hline Variable & Mean & Minimum & Maximum \\
\hline \multicolumn{4}{|l|}{ Vital Statistics Variables } \\
\hline Accidental Deaths (per 1,000) & 0.165 & 0.000 & 6.36 \\
\hline To Car Passengers & 0.031 & 0.000 & 2.00 \\
\hline All Other Accidents & 0.134 & 0.000 & 6.36 \\
\hline Cancer Deaths (per 1,000) & 0.039 & 0.000 & 4.74 \\
\hline \multicolumn{4}{|l|}{ CPS Variables } \\
\hline Maternal Employment Rate & 0.517 & 0.000 & 1.000 \\
\hline Poverty Rate & 0.159 & 0.053 & 0.277 \\
\hline Urban Share & 0.773 & 0.000 & 1.000 \\
\hline Hispanic Share & 0.167 & 0.000 & 0.554 \\
\hline Black Share & 0.140 & 0.000 & 0.900 \\
\hline Median Income $(1,000 \mathrm{~s})$ & 24.2 & 14.4 & 40.1 \\
\hline Mother High School & 0.395 & 0.229 & 0.623 \\
\hline One Parent Family & 0.252 & 0.078 & 0.622 \\
\hline \multicolumn{4}{|l|}{ Child Care Regulations } \\
\hline Child-to-Caregiver Ratio, Day Care & 10.88 & 4.000 & 22.50 \\
\hline Child-to-Caregiver Ratio, Family Homes & 5.82 & 3.000 & 15.00 \\
\hline Minimum Education Requirment & 0.613 & 0.000 & 1.00 \\
\hline Insurance Requirement & 0.377 & 0.000 & 1.00 \\
\hline$>1$ Inspection per Year Required & 0.227 & 0.000 & 1.00 \\
\hline \multicolumn{4}{|l|}{ Distribution of Cell Sizes } \\
\hline Number of Cells & 4,915 & & \\
\hline Minimum & 18 & & \\
\hline $1^{\text {st }}$ Percentile & 126 & & \\
\hline Median & 27,433 & & \\
\hline Maximum & 840,310 & & \\
\hline
\end{tabular}


Table 5: Estimates of Effects of Maternal Work Status and State Child Care Regulations on Childhood Accidents, NLSY Data

(Coefficients and Standard Errors Multiplied by 10)

\begin{tabular}{|c|c|c|c|c|c|c|c|}
\hline & All & Black & White & $<\boldsymbol{H S}$ & $H S$ & $\begin{array}{c}\text { Some } \\
\text { College }\end{array}$ & College \\
\hline \multicolumn{8}{|l|}{ Ordinary Least Squares } \\
\hline Work Status & $\begin{array}{l}-.018 \\
(.020)\end{array}$ & $\begin{array}{l}-.068 \\
(.034)\end{array}$ & $\begin{array}{l}-.006 \\
(.024)\end{array}$ & $\begin{array}{l}-.029 \\
(.050)\end{array}$ & $\begin{array}{l}-.027 \\
(.028)\end{array}$ & $\begin{array}{l}-.030 \\
(.042)\end{array}$ & $\begin{array}{l}-.027 \\
(.053)\end{array}$ \\
\hline $\mathrm{R}^{2}$ & .046 & .067 & .044 & .077 & .040 & .062 & .034 \\
\hline No. of Obs. & 44,369 & 12,137 & 32,232 & 5,218 & 18,964 & 11,213 & 6,986 \\
\hline \multicolumn{8}{|l|}{ Child Fixed Effects } \\
\hline Work Status & $\begin{array}{l}.019 \\
(.030)\end{array}$ & $\begin{array}{l}-.100 \\
(.048)\end{array}$ & $\begin{array}{l}.067 \\
(.037)\end{array}$ & $\begin{array}{l}-.054 \\
(.074)\end{array}$ & $\begin{array}{l}.011 \\
(.044)\end{array}$ & $\begin{array}{l}.097 \\
(.061)\end{array}$ & $\begin{array}{l}-.031 \\
(.089)\end{array}$ \\
\hline $\mathrm{R}^{2}$ (within) & .033 & .043 & .033 & .044 & .028 & .041 & .032 \\
\hline No. of Children & 6,206 & 1,671 & 4,535 & 731 & 2,558 & 1,446 & 914 \\
\hline No. of Obs. per Child & 7.1 & 7.3 & 7.1 & 7.1 & 7.4 & 7.8 & 7.6 \\
\hline \multicolumn{8}{|c|}{ Child Fixed Effects, Child Care Regulations and Interactions } \\
\hline Work Status & $\begin{array}{l}.132 \\
(.103)\end{array}$ & $\begin{array}{l}.260 \\
(.132)\end{array}$ & $\begin{array}{l}-.234 \\
(.162)\end{array}$ & $\begin{array}{c}.254 \\
(.268)\end{array}$ & $\begin{array}{l}-.045 \\
(.151)\end{array}$ & $\begin{array}{c}.267 \\
(.232)\end{array}$ & $\begin{array}{c}.339 \\
(.322)\end{array}$ \\
\hline Minimum Educ. Required & $\begin{array}{l}.017 \\
(.077)\end{array}$ & $\begin{array}{l}.052 \\
(.103)\end{array}$ & $\begin{array}{l}-.121 \\
(.109)\end{array}$ & $\begin{array}{l}.193 \\
(.186)\end{array}$ & $\begin{array}{l}-.040 \\
(.111)\end{array}$ & $\begin{array}{l}-.059 \\
(.167)\end{array}$ & $\begin{array}{l}-.059 \\
(.228)\end{array}$ \\
\hline$>1$ Inspections Required & $\begin{array}{l}-.207 \\
(.093)\end{array}$ & $\begin{array}{l}-.233 \\
(.117)\end{array}$ & $\begin{array}{l}-.202 \\
(.144)\end{array}$ & $\begin{array}{l}-.195 \\
(.226)\end{array}$ & $\begin{array}{l}-.217 \\
(.142)\end{array}$ & $\begin{array}{l}-.136 \\
(.189)\end{array}$ & $\begin{array}{l}-.262 \\
(.269)\end{array}$ \\
\hline Insurance Required & $\begin{array}{l}.001 \\
(.104)\end{array}$ & $\begin{array}{l}-.061 \\
(.125)\end{array}$ & $\begin{array}{l}.151 \\
(.182)\end{array}$ & $\begin{array}{l}.094 \\
(.252)\end{array}$ & $\begin{array}{l}-.169 \\
(.157)\end{array}$ & $\begin{array}{l}.150 \\
(.216)\end{array}$ & $\begin{array}{l}.191 \\
(.283)\end{array}$ \\
\hline Child-Staff Ratio, Fam. Home & $\begin{array}{l}.002 \\
(.010)\end{array}$ & $\begin{array}{l}.001 \\
(.013)\end{array}$ & $\begin{array}{l}-.000 \\
(.013)\end{array}$ & $\begin{array}{l}.004 \\
(.020)\end{array}$ & $\begin{array}{l}.006 \\
(.013)\end{array}$ & $\begin{array}{l}-.025 \\
(.028)\end{array}$ & $\begin{array}{l}-.009 \\
(.038)\end{array}$ \\
\hline Child-Staff Ratio, Day Care & $\begin{array}{l}-.004 \\
(.006)\end{array}$ & $\begin{array}{l}-.003 \\
(.008)\end{array}$ & $\begin{array}{l}-.010 \\
(.009)\end{array}$ & $\begin{array}{l}-.000 \\
(.013)\end{array}$ & $\begin{array}{l}-.007 \\
(.009)\end{array}$ & $\begin{array}{c}.002 \\
(.125)\end{array}$ & $\begin{array}{l}.005 \\
(.020)\end{array}$ \\
\hline Work $\times$ Min. Ed. Required & $\begin{array}{l}-.179 \\
(.068)\end{array}$ & $\begin{array}{l}-.232 \\
(.084)\end{array}$ & $\begin{array}{c}.004 \\
(.108)\end{array}$ & $\begin{array}{l}-.350 \\
(.166)\end{array}$ & $\begin{array}{l}-.003 \\
(.098)\end{array}$ & $\begin{array}{l}-.197 \\
(.141)\end{array}$ & $\begin{array}{l}-.479 \\
(.210)\end{array}$ \\
\hline Work $\times$ Inspections Required & $\begin{array}{l}.031 \\
(.079)\end{array}$ & $\begin{array}{l}.106 \\
(.102)\end{array}$ & $\begin{array}{l}-.068 \\
(.118)\end{array}$ & $\begin{array}{l}.386 \\
(.199)\end{array}$ & $\begin{array}{l}.120 \\
(.116)\end{array}$ & $\begin{array}{l}-.149 \\
(.163)\end{array}$ & $\begin{array}{l}-.228 \\
(.251)\end{array}$ \\
\hline Work $\times$ Insurance Required & $\begin{array}{l}.133 \\
(.078)\end{array}$ & $\begin{array}{l}.130 \\
(.094)\end{array}$ & $\begin{array}{l}.076 \\
(.138)\end{array}$ & $\begin{array}{l}.104 \\
(.197)\end{array}$ & $\begin{array}{l}.096 \\
(.114)\end{array}$ & $\begin{array}{l}.123 \\
(.171)\end{array}$ & $\begin{array}{l}-.014 \\
(.232)\end{array}$ \\
\hline Work $\times$ Child-Staff Ratio, FH & $\begin{array}{l}-.011 \\
(.012)\end{array}$ & $\begin{array}{l}-.014 \\
(.017)\end{array}$ & $\begin{array}{l}-.003 \\
(.017)\end{array}$ & $\begin{array}{l}-.033 \\
(.033)\end{array}$ & $\begin{array}{l}-.009 \\
(.018)\end{array}$ & $\begin{array}{c}.012 \\
(.030)\end{array}$ & $\begin{array}{l}-.013 \\
(.043)\end{array}$ \\
\hline Work $\times$ Child-Staff Ratio, DC & $\begin{array}{l}-.000 \\
(.005)\end{array}$ & $\begin{array}{l}-.004 \\
(.007)\end{array}$ & $\begin{array}{l}.010 \\
(.008)\end{array}$ & $\begin{array}{l}-.002 \\
(.013)\end{array}$ & $\begin{array}{l}.005 \\
(.008)\end{array}$ & $\begin{array}{l}-.012 \\
(.011)\end{array}$ & $\begin{array}{l}-.002 \\
(.017)\end{array}$ \\
\hline $\mathrm{R}^{2}$ & .038 & .038 & .048 & .055 & .031 & .048 & .042 \\
\hline No. of Obs. & 36,364 & 26,247 & 10,117 & 4,446 & 15,866 & 9,102 & 5,050 \\
\hline
\end{tabular}

Notes: OLS models included indicators for: spouse present; spouse missing; younger and older siblings present; child male, black, or Hispanic; maternal grandmother and grandfather employed when the mother was age 14; maternal grandfather information missing; mother growing up in a single parent household; maternal AFQT; maternal education (12 years, some college, 16 or more years, education missing); mother's age (20-29, 30-39); each year of child's age; quarter of the year; and year. Fixed effects models include those variables that show variation over mothers/children. Standard errors in parentheses. 
Table 6: Estimates of Effects of Maternal Employment and State Child Care Regulations on Child Death Rates, Vital Statistics Data

\begin{tabular}{|c|c|c|c|c|}
\hline & \multicolumn{4}{|c|}{ Cause of Death: } \\
\hline & $\begin{array}{c}\text { All } \\
\text { Accidents }\end{array}$ & $\begin{array}{c}\text { Accident } \\
\text { to Car } \\
\text { Passenger }\end{array}$ & $\begin{array}{c}\text { Other } \\
\text { Accidents }\end{array}$ & Cancer \\
\hline \multicolumn{5}{|l|}{ 1. No Controls } \\
\hline Share Working Moms & $\begin{array}{r}.052 \\
(.012\end{array}$ & $\begin{array}{c}.039 \\
(.004)\end{array}$ & $\begin{array}{r}.013 \\
(.010\end{array}$ & $\begin{array}{l}-.012 \\
(.004)\end{array}$ \\
\hline $\mathrm{R}^{2}$ & .278 & .024 & .324 & .017 \\
\hline \multicolumn{5}{|l|}{ 2. Full Controls } \\
\hline Share Working Moms & $\begin{array}{c}.006 \\
(.013)\end{array}$ & $\begin{array}{c}.011 \\
(.005)\end{array}$ & $\begin{array}{l}-.005 \\
(.012)\end{array}$ & $\begin{array}{c}.008 \\
(.006)\end{array}$ \\
\hline $\mathrm{R}^{2}$ & .532 & .196 & .527 & .089 \\
\hline \multicolumn{5}{|c|}{ 3. Full Controls + Child Care Regulations } \\
\hline Share Working Moms & $\begin{array}{l}-.001 \\
(.013)\end{array}$ & $\begin{array}{l}.009 \\
(.005)\end{array}$ & $\begin{array}{l}-.010 \\
(.012)\end{array}$ & $\begin{array}{l}.007 \\
(.006)\end{array}$ \\
\hline Minimum Education Required & $\begin{array}{l}-.031 \\
(.005)\end{array}$ & $\begin{array}{l}-.006 \\
(.002)\end{array}$ & $\begin{array}{l}-.024 \\
(.005)\end{array}$ & $\begin{array}{l}-.004 \\
(.002)\end{array}$ \\
\hline$>1$ Inspections Required & $\begin{array}{l}-.024 \\
(.008)\end{array}$ & $\begin{array}{l}-.007 \\
(.003)\end{array}$ & $\begin{array}{l}-.016 \\
(.008)\end{array}$ & $\begin{array}{l}-.005 \\
(.004)\end{array}$ \\
\hline Insurance Required & $\begin{array}{l}-.038 \\
(.011)\end{array}$ & $\begin{array}{l}-.009 \\
(.004)\end{array}$ & $\begin{array}{l}-.029 \\
(.010)\end{array}$ & $\begin{array}{l}-.005 \\
(.005)\end{array}$ \\
\hline Child-Staff Ratio, Family Homes & $\begin{array}{l}.003 \\
(.001)\end{array}$ & $\begin{array}{l}-.001 \\
(.001)\end{array}$ & $\begin{array}{l}.003 \\
(.001)\end{array}$ & $\begin{array}{c}.000 \\
(.001)\end{array}$ \\
\hline Child-Staff Ratio, Day Care & $\begin{array}{l}-.003 \\
(.001)\end{array}$ & $\begin{array}{l}-.0002 \\
(.0003)\end{array}$ & $\begin{array}{l}-.003 \\
(.001)\end{array}$ & $\begin{array}{l}-.0002 \\
(.0003)\end{array}$ \\
\hline Child Black & $\begin{array}{l}.081 \\
(.003)\end{array}$ & $\begin{array}{l}.002 \\
(.001)\end{array}$ & $\begin{array}{l}.080 \\
(.003)\end{array}$ & $\begin{array}{l}-.004 \\
(.001)\end{array}$ \\
\hline Child 1-3 & $\begin{array}{l}.047 \\
(.005)\end{array}$ & $\begin{array}{l}-.002 \\
(.002)\end{array}$ & $\begin{array}{l}.049 \\
(.005)\end{array}$ & $\begin{array}{l}-.002 \\
(.002)\end{array}$ \\
\hline Child Male & $\begin{array}{l}.063 \\
(.002)\end{array}$ & $\begin{array}{l}.002 \\
(.001)\end{array}$ & $\begin{array}{c}.061 \\
(.002)\end{array}$ & $\begin{array}{c}.007 \\
(.001)\end{array}$ \\
\hline Share One-Parent Families & $\begin{array}{l}.172 \\
(.052)\end{array}$ & $\begin{array}{l}-.011 \\
(.020)\end{array}$ & $\begin{array}{l}.183 \\
(.047)\end{array}$ & $\begin{array}{c}.035 \\
(.022)\end{array}$ \\
\hline Share Poor & $\begin{array}{l}-.190 \\
(.101)\end{array}$ & $\begin{array}{l}-.67 \\
(.038)\end{array}$ & $\begin{array}{l}-.122 \\
(.092)\end{array}$ & $\begin{array}{l}-.057 \\
(.043)\end{array}$ \\
\hline Share Urban & $\begin{array}{l}-.014 \\
(.015)\end{array}$ & $\begin{array}{l}-.001 \\
(.006)\end{array}$ & $\begin{array}{l}-.013 \\
(.014)\end{array}$ & $\begin{array}{l}-.005 \\
(.006)\end{array}$ \\
\hline Share Black & $\begin{array}{l}.013 \\
(.059)\end{array}$ & $\begin{array}{l}.015 \\
(.022)\end{array}$ & $\begin{array}{l}-.002 \\
(.053)\end{array}$ & $\begin{array}{l}-.007 \\
(.025)\end{array}$ \\
\hline Share Hispanic & $\begin{array}{l}-.421 \\
(.055)\end{array}$ & $\begin{array}{l}-.062 \\
(.021)\end{array}$ & $\begin{array}{l}-.360 \\
(.050)\end{array}$ & $\begin{array}{l}-.095 \\
(.023)\end{array}$ \\
\hline Median Income $(10,000 \mathrm{~s})$ & $\begin{array}{c}.017 \\
(.012)\end{array}$ & $\begin{array}{l}.005 \\
(.005)\end{array}$ & $\begin{array}{c}.012 \\
(.011)\end{array}$ & $\begin{array}{l}-.008 \\
(.005)\end{array}$ \\
\hline Share HS Educated Mothers & $\begin{array}{l}.008 \\
(.037)\end{array}$ & $\begin{array}{l}.004 \\
(.014)\end{array}$ & $\begin{array}{l}.004 \\
(.033)\end{array}$ & $\begin{array}{l}-.016 \\
(.015)\end{array}$ \\
\hline 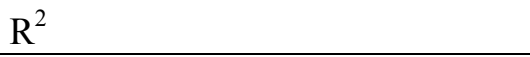 & .539 & .199 & .534 & .090 \\
\hline
\end{tabular}


Table 7: Estimates of Effects of Maternal Employment and State Child Care Regulations on Child Death Rates, By Race, Vital Statistics Data

\begin{tabular}{|c|c|c|c|c|c|c|c|c|}
\hline \multirow[b]{2}{*}{ Cause of Death: } & \multicolumn{4}{|c|}{ Whites: } & \multicolumn{4}{|c|}{ Blacks: } \\
\hline & $\begin{array}{c}\text { All } \\
\text { Accidents }\end{array}$ & $\begin{array}{c}\text { Car } \\
\text { Passenger }\end{array}$ & $\begin{array}{c}\text { Other } \\
\text { Accidents }\end{array}$ & Cancer & $\begin{array}{c}\text { All } \\
\text { Accidents }\end{array}$ & $\begin{array}{c}\text { Car } \\
\text { Passenger }\end{array}$ & $\begin{array}{c}\text { Other } \\
\text { Accidents }\end{array}$ & Cancer \\
\hline \multirow[t]{2}{*}{ Share Working Mothers } & .036 & .009 & .027 & .020 & .010 & .001 & .009 & -.001 \\
\hline & $(.021)$ & $(.008)$ & $(.018)$ & $(.009)$ & $(.019)$ & $(.007)$ & $(.018)$ & $(.008)$ \\
\hline \multirow[t]{2}{*}{ Minimum Education Required } & -.025 & -.008 & -.017 & -.004 & -.045 & -.002 & -.043 & -.005 \\
\hline & $(.006)$ & $(.002)$ & $(.005)$ & $(.003)$ & $(.012)$ & $(.004)$ & $(.011)$ & $(.005)$ \\
\hline \multirow[t]{2}{*}{$>1$ Inspection Required } & -.014 & -.005 & -.010 & -.004 & -.068 & -.021 & -.047 & -.007 \\
\hline & $(.009)$ & $(.004)$ & $(.008)$ & $(.004)$ & $(.021)$ & $(.008)$ & $(.019)$ & $(.009)$ \\
\hline \multirow[t]{2}{*}{ Insurance Required } & -.049 & -.011 & -.039 & -.005 & .050 & .013 & .038 & -.004 \\
\hline & $(.012)$ & $(.005)$ & $(.010)$ & $(.005)$ & $(.034)$ & $(.13)$ & $(.032)$ & $(.014)$ \\
\hline \multirow[t]{2}{*}{ Child-to-Staff Ratio, Fam. Homes } & .004 & -.000 & .004 & .000 & -.006 & -.003 & -.003 & -.000 \\
\hline & $(.002)$ & $(.001)$ & $(.001)$ & $(.001)$ & $(.004)$ & $(.001)$ & $(.003)$ & $(.002)$ \\
\hline \multirow[t]{2}{*}{ Child-to-Staff Ratio, Day Care } & -.003 & -.0002 & -.003 & -.0004 & -.007 & -.000 & -.006 & .000 \\
\hline & $(.001)$ & $(.0003)$ & $(.001)$ & $(.0003)$ & $(.002)$ & $(.001)$ & $(.002)$ & $(.001)$ \\
\hline $\mathrm{R}^{2}$ & .602 & .264 & .603 & .142 & .352 & .160 & & .052 \\
\hline
\end{tabular}

Notes: Regressions include all of the CPS variables listed in Table 5 as well as state and year effects and 2 controls for child age and sex. There are 2,660 cells for whites and 2,255 cells for blacks. Standard errors in parentheses. 


\section{Table 8: Multinomial Logit Estimates of Effects of State Child Care Regulations on Choice of Child Care, NLSY Data}

\begin{tabular}{|c|c|c|c|c|c|c|c|}
\hline & All & Black & White & $<\boldsymbol{H S}$ & $H S$ & $\begin{array}{l}\text { Some } \\
\text { College }\end{array}$ & College \\
\hline \multicolumn{8}{|c|}{ Day Care Centers, Family Group Homes, and Preschools } \\
\hline \multirow[t]{2}{*}{ Minimum Education Required } & $\begin{array}{l}-.231 \\
(.130)\end{array}$ & $\begin{array}{l}-.273 \\
(.236)\end{array}$ & $\begin{array}{l}-.245 \\
(.159)\end{array}$ & $\begin{array}{l}-.443 \\
(.646)\end{array}$ & $\begin{array}{l}-.269 \\
(.215)\end{array}$ & $\begin{array}{l}-.422 \\
(.234)\end{array}$ & $\begin{array}{l}-.060 \\
(.286)\end{array}$ \\
\hline & {$[.794]$} & {$[.761]$} & {$[.782]$} & {$[.642]$} & {$[.764]$} & {$[.656]$} & {$[.942]$} \\
\hline \multirow[t]{3}{*}{$>1$ Inspections Required } & -.097 & -.549 & .072 & -.981 & -.041 & -.202 & .117 \\
\hline & $(.142)$ & $(.242)$ & $(.178)$ & $(.805)$ & $(.221)$ & $(.274)$ & $(.327)$ \\
\hline & {$[.908]$} & {$[.578]$} & {$[1.07]$} & {$[.375]$} & {$[.960]$} & {$[.817]$} & {$[1.12]$} \\
\hline \multirow[t]{3}{*}{ Insurance Required } & -.450 & -.596 & -.421 & -2.46 & -.436 & -.123 & -.891 \\
\hline & $(.149)$ & $(.281)$ & $(.182)$ & $(.963)$ & $(.245)$ & $(.276)$ & $(.324)$ \\
\hline & {$[.637]$} & {$[.551]$} & {$[.656]$} & {$[.085]$} & {$[.647]$} & {$[.885]$} & {$[.410]$} \\
\hline \multirow[t]{3}{*}{ Child-Staff Ratio, Fam. Homes } & -.001 & -.029 & .027 & -.553 & -.027 & .048 & .002 \\
\hline & $(.025)$ & $(.042)$ & $(.031)$ & $(.206)$ & $(.045)$ & $(.037)$ & $(.057)$ \\
\hline & [.999] & {$[.972]$} & [1.03] & $.575]$ & {$[.973]$} & {$[1.05]$} & {$[1.00]$} \\
\hline \multirow[t]{3}{*}{ Child-Staff Ratio, Day Care } & .062 & -.018 & .107 & .004 & .107 & .012 & .037 \\
\hline & $(.020)$ & $(.033)$ & $(.026)$ & $(.110)$ & $(.038)$ & $(.046)$ & $(.047)$ \\
\hline & {$[1.06]$} & {$[.982]$} & [1.11] & {$[1.00]$} & {$[1.11]$} & {$[1.01]$} & {$[1.04]$} \\
\hline \multicolumn{8}{|l|}{ Other Child Care } \\
\hline \multirow[t]{3}{*}{ Minimum Education Required } & .007 & -.166 & .061 & .048 & .084 & -.013 & -.096 \\
\hline & $(.093)$ & $(.198)$ & $(.105)$ & $(.387)$ & $(.143)$ & $(.186)$ & $(.215)$ \\
\hline & {$[1.01]$} & {$[.847]$} & {$[1.06]$} & {$[1.05]$} & [1.09] & {$[.987]$} & {$[.908]$} \\
\hline \multirow[t]{3}{*}{$>1$ Inspections Required } & -.060 & -.515 & -.081 & -.575 & -.133 & .081 & .146 \\
\hline & $(.104)$ & $(.198)$ & $(.124)$ & $(.411)$ & $(.163)$ & $(.197)$ & $(.256)$ \\
\hline & [.942] & {$[.598]$} & {$[1.08]$} & {$[.563]$} & {$[.876]$} & {$[1.08]$} & [1.16] \\
\hline \multirow[t]{3}{*}{ Insurance Required } & -.115 & -.545 & .002 & -.366 & -.012 & -.095 & -.310 \\
\hline & $(.100)$ & $(.222)$ & $(.114)$ & $(.490)$ & $(.160)$ & $(.190)$ & $(.246)$ \\
\hline & {$[.892]$} & {$[.580]$} & {$[1.00]$} & [.693] & {$[.988]$} & {$[.909]$} & {$[.734]$} \\
\hline \multirow[t]{3}{*}{ Child-Staff Ratio, Fam. Homes } & -.040 & -.073 & -.023 & .002 & -.047 & -.055 & -.047 \\
\hline & $(.018)$ & $(.039)$ & $(.021)$ & $(.078)$ & $(.029)$ & $(.034)$ & $(.049)$ \\
\hline & {$[.961]$} & {$[.930]$} & {$[.977]$} & {$[1.00]$} & {$[.954]$} & {$[.946]$} & {$[.954]$} \\
\hline \multirow[t]{3}{*}{ Child-Staff Ratio, Day Care } & .011 & -.038 & .021 & .037 & .057 & -.031 & -.033 \\
\hline & $(.017)$ & $(.034)$ & $(.021)$ & $(.051)$ & $(.028)$ & $(.035)$ & $(.043)$ \\
\hline & {$[1.01]$} & {$[.963]$} & [1.02] & [1.04] & [1.06] & {$[.969]$} & {$[.968]$} \\
\hline No. of Observations & 9223 & 2544 & 6679 & 893 & 3918 & 2521 & 1653 \\
\hline Psuedo- $\mathrm{R}^{2}$ & .129 & .144 & .137 & .313 & .136 & .121 & .154 \\
\hline
\end{tabular}

Notes: Standard errors in parentheses. Log odds in brackets. Omitted category is "no maternal care". Models included the same set of control variables as Appendix Table 1, except that they do not include maternal work status. 
Appendix 1: OLS Estimates of Effects of Additional Variables for Child Accident Regressions in Table 5, NLSY Data (Coefficients and Standard Errors $\times 10$ )

\begin{tabular}{|c|c|c|c|c|c|c|c|}
\hline & All & Black & White & $<\boldsymbol{H S}$ & $H S$ & $\begin{array}{c}\text { Some } \\
\text { College }\end{array}$ & College \\
\hline Mother Works & $\begin{array}{l}-.018 \\
(.020)\end{array}$ & $\begin{array}{l}.068 \\
(.034)\end{array}$ & $\begin{array}{l}.006 \\
(.023)\end{array}$ & $\begin{array}{l}.029 \\
(.050)\end{array}$ & $\begin{array}{l}-.027 \\
(.028)\end{array}$ & $\begin{array}{l}-.030 \\
(.042)\end{array}$ & $\begin{array}{l}-.027 \\
(.053)\end{array}$ \\
\hline Spouse present & $\begin{array}{l}-.027 \\
(.039)\end{array}$ & $\begin{array}{c}.021 \\
(.050)\end{array}$ & $\begin{array}{l}-.053 \\
(.056)\end{array}$ & $\begin{array}{l}-.035 \\
(.089)\end{array}$ & $\begin{array}{c}.016 \\
(.050)\end{array}$ & $\begin{array}{l}-.034 \\
(.081)\end{array}$ & $\begin{array}{l}-.228 \\
(.127)\end{array}$ \\
\hline Spouse info. missing & $\begin{array}{c}.058 \\
(.119)\end{array}$ & $\begin{array}{c}.112 \\
(.203)\end{array}$ & $\begin{array}{l}-.0008 \\
(.146)\end{array}$ & $\begin{array}{l}-.220 \\
(.231)\end{array}$ & $\begin{array}{c}.329 \\
(.216)\end{array}$ & $\begin{array}{l}.105 \\
(.296)\end{array}$ & $\begin{array}{l}-.478 \\
(.143)\end{array}$ \\
\hline Younger sibling present & $\begin{array}{l}-.058 \\
(.022)\end{array}$ & $\begin{array}{l}-.094 \\
(.033)\end{array}$ & $\begin{array}{l}-.039 \\
(.027)\end{array}$ & $\begin{array}{l}-.106 \\
(.049)\end{array}$ & $\begin{array}{l}-.019 \\
(.034)\end{array}$ & $\begin{array}{l}-.055 \\
(.041)\end{array}$ & $\begin{array}{l}-.089 \\
(.052)\end{array}$ \\
\hline Older sibling present & $\begin{array}{l}.054 \\
(.021)\end{array}$ & $\begin{array}{l}-.001 \\
(.038)\end{array}$ & $\begin{array}{l}.076 \\
(.025)\end{array}$ & $\begin{array}{l}-.013 \\
(.063)\end{array}$ & $\begin{array}{l}.031 \\
(.030)\end{array}$ & $\begin{array}{l}.033 \\
(.040)\end{array}$ & $\begin{array}{l}.131 \\
(.051)\end{array}$ \\
\hline Male & $\begin{array}{l}.101 \\
(.019)\end{array}$ & $\begin{array}{l}.125 \\
(.031)\end{array}$ & $\begin{array}{l}.088 \\
(.023)\end{array}$ & $\begin{array}{l}.122 \\
(.049)\end{array}$ & $\begin{array}{l}.091 \\
(.028)\end{array}$ & $\begin{array}{l}.105 \\
(.036)\end{array}$ & $\begin{array}{l}.130 \\
(.048)\end{array}$ \\
\hline Hispanic & $\begin{array}{l}-.116 \\
(.031)\end{array}$ & & $\begin{array}{l}-.127 \\
(.032)\end{array}$ & $\begin{array}{l}-.074 \\
(.080)\end{array}$ & $\begin{array}{l}-.117 \\
(.044)\end{array}$ & $\begin{array}{l}-.108 \\
(.059)\end{array}$ & $\begin{array}{l}-.114 \\
(.090)\end{array}$ \\
\hline Black & $\begin{array}{l}-.140 \\
(.028)\end{array}$ & & & $\begin{array}{l}-.213 \\
(.084)\end{array}$ & $\begin{array}{l}-.082 \\
(.038)\end{array}$ & $\begin{array}{l}-.192 \\
(.052)\end{array}$ & $\begin{array}{l}-.057 \\
(.087)\end{array}$ \\
\hline Grandmother worked & $\begin{array}{l}.015 \\
(.020)\end{array}$ & $\begin{array}{l}-.006 \\
(.035)\end{array}$ & $\begin{array}{l}.021 \\
(.024)\end{array}$ & $\begin{array}{l}.055 \\
(.052)\end{array}$ & $\begin{array}{l}-.046 \\
(.029)\end{array}$ & $\begin{array}{c}.032 \\
(.037)\end{array}$ & $\begin{array}{l}.062 \\
(.052)\end{array}$ \\
\hline Grandfather worked & $\begin{array}{l}.036 \\
(.037)\end{array}$ & $\begin{array}{l}.099 \\
(.048)\end{array}$ & $\begin{array}{l}.010 \\
(.047)\end{array}$ & $\begin{array}{l}.174 \\
(.091)\end{array}$ & $\begin{array}{l}.006 \\
(.053)\end{array}$ & $\begin{array}{c}.093 \\
(.058)\end{array}$ & $\begin{array}{l}.130 \\
(.090)\end{array}$ \\
\hline Missing grandparent info. & $\begin{array}{l}.045 \\
(.041)\end{array}$ & $\begin{array}{c}.075 \\
(.051)\end{array}$ & $\begin{array}{l}.048 \\
(.055)\end{array}$ & $\begin{array}{l}.200 \\
(.099)\end{array}$ & $\begin{array}{l}.017 \\
(.058)\end{array}$ & $\begin{array}{l}.115 \\
(.068)\end{array}$ & $\begin{array}{l}.022 \\
(.110)\end{array}$ \\
\hline Single & $\begin{array}{l}.053 \\
(.037)\end{array}$ & $\begin{array}{l}.028 \\
(.042)\end{array}$ & $\begin{array}{l}.080 \\
(.054)\end{array}$ & $\begin{array}{l}.065 \\
(.086)\end{array}$ & $\begin{array}{l}.039 \\
(.047)\end{array}$ & $\begin{array}{l}.104 \\
(.081)\end{array}$ & $\begin{array}{l}.021 \\
(.109)\end{array}$ \\
\hline AFQT score & $\begin{array}{l}.002 \\
(.0006)\end{array}$ & $\begin{array}{c}.003 \\
(.001)\end{array}$ & $\begin{array}{l}.002 \\
(.0007)\end{array}$ & $\begin{array}{c}.003 \\
(.003)\end{array}$ & $\begin{array}{l}.002 \\
(.0008)\end{array}$ & $\begin{array}{c}.003 \\
(.001)\end{array}$ & $\begin{array}{l}.002 \\
(.001)\end{array}$ \\
\hline Education missing & $\begin{array}{l}.107 \\
(.077)\end{array}$ & $\begin{array}{c}.061 \\
(.210)\end{array}$ & $\begin{array}{l}.077 \\
(.082)\end{array}$ & & & & \\
\hline High School Education & $\begin{array}{c}.016 \\
(.031)\end{array}$ & $\begin{array}{c}.079 \\
(.041)\end{array}$ & $\begin{array}{l}-.023 \\
(.040)\end{array}$ & & & & \\
\hline Some College & $\begin{array}{c}.031 \\
(.036)\end{array}$ & $\begin{array}{c}.038 \\
(.049)\end{array}$ & $\begin{array}{l}.015 \\
(.046)\end{array}$ & & & & \\
\hline
\end{tabular}




\begin{tabular}{|c|c|c|c|c|c|c|c|}
\hline & All & Black & White & $<\boldsymbol{H S}$ & $H S$ & $\begin{array}{c}\text { Some } \\
\text { College }\end{array}$ & College \\
\hline College + & $\begin{array}{l}-.012 \\
(.049)\end{array}$ & $\begin{array}{l}.056 \\
(.097)\end{array}$ & $\begin{array}{l}-.059 \\
(.056)\end{array}$ & & & & \\
\hline Maternal grandma, Educ. & .042 & .100 & .0006 & .044 & .011 & .046 & -.029 \\
\hline & $(.044)$ & $(.066)$ & $(.057)$ & $(.073)$ & $(.067)$ & $(.084)$ & $(.117)$ \\
\hline Maternal grandma, HS & $\begin{array}{c}.017 \\
(.026)\end{array}$ & $\begin{array}{l}.010 \\
(.034)\end{array}$ & $\begin{array}{l}.025 \\
(.033)\end{array}$ & $\begin{array}{c}.051 \\
(.065)\end{array}$ & $\begin{array}{l}.007 \\
(.034)\end{array}$ & $\begin{array}{l}-.002 \\
(.046)\end{array}$ & $\begin{array}{l}-.023 \\
(.080)\end{array}$ \\
\hline Maternal grandma, Some College & $\begin{array}{l}-.018 \\
(.044)\end{array}$ & $\begin{array}{l}-.202 \\
(.095)\end{array}$ & $\begin{array}{l}.037 \\
(.047)\end{array}$ & $\begin{array}{c}.084 \\
(.186)\end{array}$ & $\begin{array}{l}-.069 \\
(.067)\end{array}$ & $\begin{array}{l}-.026 \\
(.063)\end{array}$ & $\begin{array}{l}-.044 \\
(.086)\end{array}$ \\
\hline Maternal Grandma, College + & $\begin{array}{c}.032 \\
(.054)\end{array}$ & $\begin{array}{l}.162 \\
(.126)\end{array}$ & $\begin{array}{c}.023 \\
(.061)\end{array}$ & $\begin{array}{l}-.152 \\
(.105)\end{array}$ & $\begin{array}{l}-.142 \\
(.142)\end{array}$ & $\begin{array}{l}.135 \\
(.088)\end{array}$ & $\begin{array}{l}-.045 \\
(.096)\end{array}$ \\
\hline Mother's age 20-29 & $\begin{array}{c}-.97 \\
(1.59)\end{array}$ & $\begin{array}{l}-6.98 \\
(1.26)\end{array}$ & $\begin{array}{c}1.17 \\
(1.26)\end{array}$ & $\begin{array}{c}2.70 \\
(1.43)\end{array}$ & $\begin{array}{r}-.944 \\
(1.80)\end{array}$ & $\begin{array}{l}-6.68 \\
(1.82)\end{array}$ & $\begin{array}{l}-.016 \\
(.065)\end{array}$ \\
\hline Mother's age 30-39 & $\begin{array}{l}-1.00 \\
(1.59)\end{array}$ & $\begin{array}{l}-7.03 \\
(1.26)\end{array}$ & $\begin{array}{c}1.14 \\
(1.26)\end{array}$ & $\begin{array}{c}2.71 \\
(1.43)\end{array}$ & $\begin{array}{r}-.995 \\
(1.80)\end{array}$ & $\begin{array}{l}-6.82 \\
(1.82)\end{array}$ & \\
\hline Child $1-2$ years old & $\begin{array}{l}-.011 \\
(.029)\end{array}$ & $\begin{array}{c}.010 \\
(.051)\end{array}$ & $\begin{array}{l}-.009 \\
(.034)\end{array}$ & $\begin{array}{l}-.162 \\
(.071)\end{array}$ & $\begin{array}{c}.002 \\
(.040)\end{array}$ & $\begin{array}{c}.029 \\
(.060)\end{array}$ & $\begin{array}{c}.042 \\
(.073)\end{array}$ \\
\hline Child 2-3 years old & $\begin{array}{c}.024 \\
(.028)\end{array}$ & $\begin{array}{l}-.026 \\
(.043)\end{array}$ & $\begin{array}{l}.053 \\
(.035)\end{array}$ & $\begin{array}{l}-.060 \\
(.075)\end{array}$ & $\begin{array}{l}.057 \\
(.040)\end{array}$ & $\begin{array}{l}.029 \\
(.060)\end{array}$ & $\begin{array}{l}.054 \\
(.073)\end{array}$ \\
\hline Child 3-4 years old & $\begin{array}{c}.049 \\
(.028)\end{array}$ & $\begin{array}{l}.043 \\
(.046)\end{array}$ & $\begin{array}{l}.055 \\
(.034)\end{array}$ & $\begin{array}{l}-.147 \\
(.067)\end{array}$ & $\begin{array}{l}.073 \\
(.041)\end{array}$ & $\begin{array}{l}.004 \\
(.055)\end{array}$ & $\begin{array}{l}.183 \\
(.073)\end{array}$ \\
\hline Child $4-5$ years old & $\begin{array}{l}-.021 \\
(.025)\end{array}$ & $\begin{array}{l}-.028 \\
(.039)\end{array}$ & $\begin{array}{l}-.013 \\
(.031)\end{array}$ & $\begin{array}{l}-.085 \\
(.068)\end{array}$ & $\begin{array}{l}.036 \\
(.037)\end{array}$ & $\begin{array}{l}-.070 \\
(.050)\end{array}$ & $\begin{array}{l}-.048 \\
(.063)\end{array}$ \\
\hline Fall & $\begin{array}{c}.577 \\
(.068)\end{array}$ & $\begin{array}{c}.432 \\
(.121)\end{array}$ & $\begin{array}{l}.647 \\
(.082)\end{array}$ & $\begin{array}{c}.400 \\
(.157)\end{array}$ & $\begin{array}{l}.404 \\
(.101)\end{array}$ & $\begin{array}{l}1.13 \\
(.144)\end{array}$ & $\begin{array}{c}.622 \\
(.156)\end{array}$ \\
\hline Summer & $\begin{array}{c}.707 \\
(.070)\end{array}$ & $\begin{array}{l}.534 \\
(.125)\end{array}$ & $\begin{array}{l}.786 \\
(.084)\end{array}$ & $\begin{array}{c}.461 \\
(.150)\end{array}$ & $\begin{array}{l}.542 \\
(.105)\end{array}$ & $\begin{array}{l}1.19 \\
(.150)\end{array}$ & $\begin{array}{c}.838 \\
(.168)\end{array}$ \\
\hline Spring & $\begin{array}{l}.238 \\
(.031)\end{array}$ & $\begin{array}{l}.158 \\
(.051)\end{array}$ & $\begin{array}{l}.276 \\
(.039)\end{array}$ & $\begin{array}{l}.166 \\
(.075)\end{array}$ & $\begin{array}{l}.211 \\
(.048)\end{array}$ & $\begin{array}{c}.358 \\
(.059)\end{array}$ & $\begin{array}{l}.390 \\
(.082)\end{array}$ \\
\hline Number of Observations & 44,369 & 12,137 & 32,232 & 5,218 & 18,964 & 11,213 & 6,986 \\
\hline
\end{tabular}

